In collaboration with the Evansville Area Earthquake Hazards Mapping Project (EAEHMP)

\title{
Probabilistic Seismic Hazard Assessment Including Site Effects for Evansville, Indiana, and the Surrounding Region
}

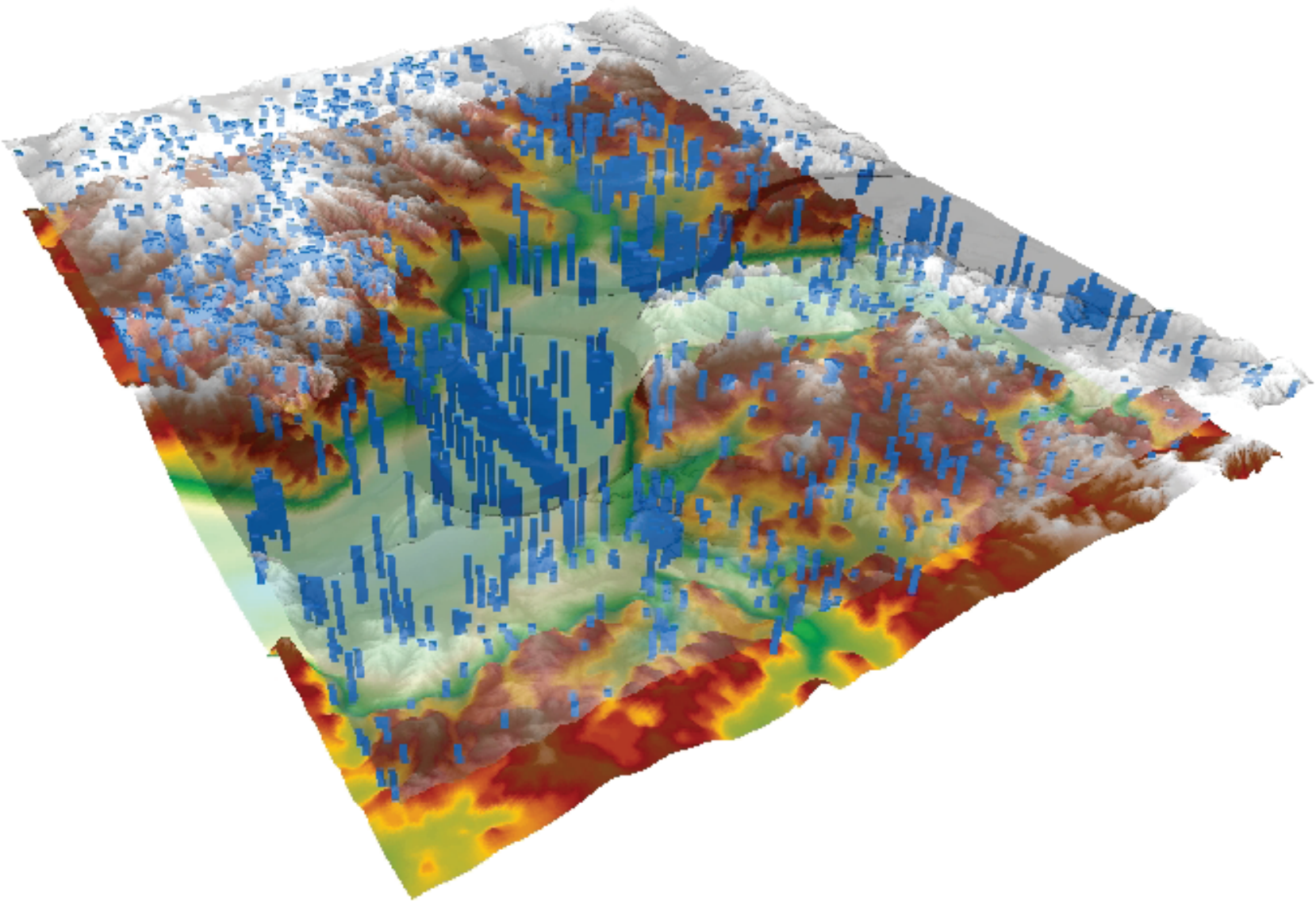

Open-File Report 2011-1231 


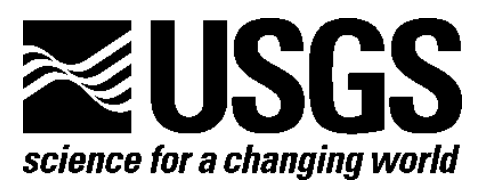

\section{Probabilistic Seismic Hazard Assessment Including Site Effects for Evansville, Indiana, and the Surrounding Region}

By Jennifer S. Haase, Tim Bowling, Robert L. Nowack, Yoon S. Choi, Chris H. Cramer, Oliver S. Boyd, and Robert A. Bauer

In collaboration with the Evansville Area Earthquake Hazards Mapping Project (EAEHMP)

Open-File Report 2011-1231

U.S. Department of the Interior

U.S. Geological Survey 


\section{U.S. Department of the Interior \\ KEN SALAZAR, Secretary}

\section{U.S. Geological Survey \\ Marcia K. McNutt, Director}

U.S. Geological Survey, Reston, Virginia: 2011

For product and ordering information:

World Wide Web: http://www.usgs.gov/pubprod

Telephone: 1-888-ASK-USGS

For more information on the USGS-the Federal source for science about the Earth, its natural and living resources, natural hazards, and the environment:

World Wide Web: http://www.usgs.gov

Telephone: 1-888-ASK-USGS

Suggested citation:

Haase, J.S., Bowling, Tim, Nowack, R.L., Choi, Y.S., Cramer, C.H., Boyd, O.S., and Bauer, R.A., 2011, Probabilistic seismic hazard assessment including site effects for Evansville, Indiana, and the surrounding region: U.S. Geological Survey Open-File Report 2011-1231, 29 p.

Any use of trade, product, or firm names is for descriptive purposes only and does not imply endorsement by the U.S. Government.

Although this report is in the public domain, permission must be secured from the individual copyright owners to reproduce any copyrighted material contained within this report. 


\section{Contents}

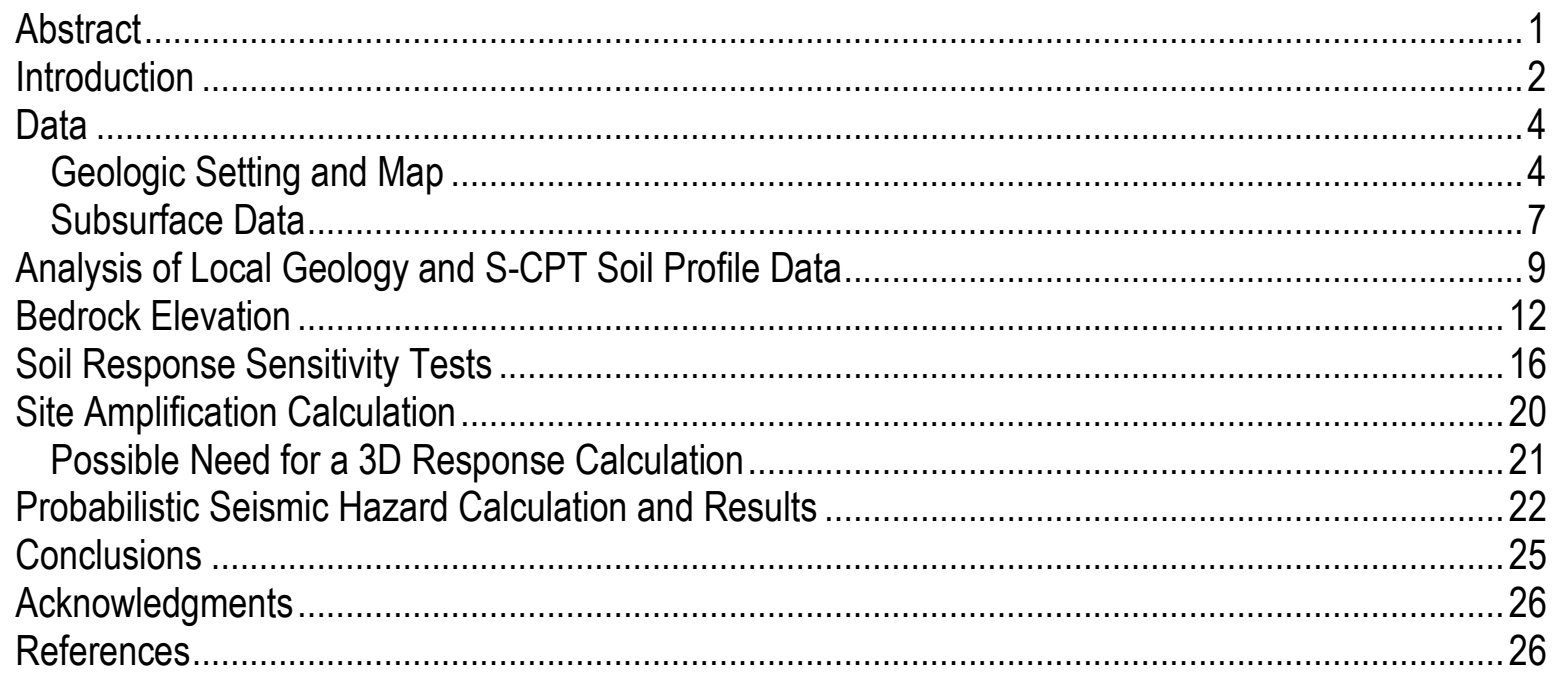

\section{Figures}

Figure 1. 2008 USGS national seismic hazard map shown for the Indiana region for 2 percent probability of exceedance in 50 years at (left) peak ground acceleration (middle)

0.2 -second (s) spectral acceleration (SA) and (right) 1.0-s SA ....................................

Figure 2. Merged surficial geologic map from the 1:50,000- and 1:500,000-scale maps including cone-penetrometer test sites with shear wave measurements

Figure 3. Locations of subsurface observations available in the Evansville region .........................8

Figure 4. Examples of soil-type profiles from the S-CPT data from the outwash terrace alluvium, flood plain river alluvium, and lacustrine terrace environments

Figure 5. Depth-dependent soil average shear-wave velocity models for (left) river alluvium, (center-left) outwash terrace, (center-right) lacustrine terrace, and (right) loess groups determined from the S-CPT profiles

Figure 6. Assignment of velocity profile characteristics at $1 \mathrm{~km}$ grid cell size ............................12

Figure 7. Left: Contoured bedrock depth (m). Right: contoured bedrock elevation (m ASL).........14

Figure 8. Perspective views of the surface digital elevation model (DEM), depth measurements, and derived bedrock elevation, with $250 \mathrm{~m}$ of offset separating the two surfaces for visibility

Figure 9. Comparison of normalized spectral response from the alluvial group depth-dependent model and three CPT profiles from within the region assigned to the alluvial group.......17

Figure 10. Normalized spectral response for the 16 ground motions listed in table 3 for (left column) the depth-dependent alluvial group profile and (right column) CPT profile VHC018.......19

Figure 11. Results of the calculation of site amplification relative to input bedrock ground motion..22

Figure 12. (top) Comparison of probabilistic seismic hazard analysis including site effects (inset) with the USGS 2008 national maps for NEHRP site class B/C shown in the surrounding background, (bottom) 


\section{Tables}

Table 1. Descriptions of subsurface observations available in the Evansville region .....................7

Table 2. Depth-dependent average shear-wave velocities for the river alluvium, outwash terrace, lacustrine terrace and loess groups. Depth to the top of the layer is given. ( $\sigma$, standard deviation, $\mathrm{m}$, meters, $\mathrm{m} / \mathrm{s}$, meters per second).......................................................

Table 3. Suite of input bedrock ground motion time histories used in site response calculation. .16 


\title{
Probabilistic Seismic Hazard Assessment Including Site Effects for Evansville, Indiana, and the Surrounding Region
}

By Jennifer S. Haase,,$^{1}$ Tim Bowling,,$^{1}$ Robert L. Nowack, ${ }^{1}$ Yoon S. Choi, ${ }^{2}$ Chris H. Cramer, ${ }^{3}$ Oliver S. Boyd, ${ }^{4}$ and Robert A. Bauer ${ }^{5}$

\begin{abstract}
We provide a probabilistic seismic hazard assessment for the Evansville, Indiana region incorporating information from new surficial geologic mapping efforts on the part of the U.S. Geological Survey (USGS) and the Kentucky and Indiana State Geological Surveys, as well as information on the thickness and properties of near surface soils and their associated uncertainties. The subsurface information has been compiled to determine bedrock elevation and reference depth-dependent shear-wave velocity models for the different soil types. The probabilistic seismic hazard calculation applied here follows the method used for the 2008 U.S. Geological Survey National Seismic Hazard Maps, with modifications to incorporate estimates of local site conditions and their uncertainties, in a completely probabilistic manner. The resulting analysis shows strong local variations of acceleration with 2 percent probability of exceedance in 50 years, particularly for $0.2-$ second (s) period spectral acceleration (SA), that are clearly correlated with variations in the thickness of unconsolidated soils above bedrock. These values are much greater than the USGS national seismic hazard map values, which assume $\mathrm{B} / \mathrm{C}$ site conditions. When compared to the national maps with an assumed uniform site D class amplification factor applied, the high-resolution seismic hazard maps have higher amplitudes for peak ground acceleration and 0.2-s SA for most of the map region. However, deamplification relative to the D class national seismic hazard maps appears to play an important role within the limits of the ancient bedrock valley underlying Evansville where soils are thickest. For 1.0-s SA, the new high-resolution seismic hazard maps show levels consistent with D class site response within the limits of this ancient bedrock valley, but levels consistent with $\mathrm{B} / \mathrm{C}$ site conditions outside.
\end{abstract}

\footnotetext{
${ }^{1}$ Department of Earth and Atmospheric Sciences, Purdue University, West Lafayette, IN 47906.

${ }^{2}$ School of Civil Engineering, Purdue University, West Lafayette, IN.

${ }^{3}$ Center for Earthquake Research and Information, University of Memphis, Memphis, TN.

${ }^{4}$ United States Geological Survey, Memphis, TN.

${ }^{5}$ Illinois State Geological Survey, Champaign, IL.
} 


\section{Introduction}

The central United States has a low rate of seismicity, but because of the occurrence of past strong to major earthquakes such as the 1811-1812 New Madrid events, as well as prehistoric earthquakes in the New Madrid and Wabash Valley seismic zones, there is a significant seismic hazard. Evansville, Indiana, is one of the closest large urban areas to both zones. For this reason, it has been targeted as a priority region for urban seismic hazard assessment.

The three major New Madrid earthquakes that occurred in 1811-1812 generated ground shaking throughout the central and eastern United States. Moment magnitudes $\left(\mathrm{M}_{\mathrm{w}}\right)$ ranging from 7.4 to 8.1 have been assigned to the largest of the earthquakes based on intensity reports (Johnston, 1996; Hough and others, 2000; Bakun and Hopper, 2004). In southwestern Indiana, the reported intensities ranged from Modified Mercalli Intensity (MMI) VI to VII (Nuttli, 1973; Street, 1984). A recurrence of a New Madrid-type event of this size is of concern in regional urban areas such as Evansville, Indiana, where earthquake damage could occur.

The U.S. Geological Survey (USGS) has carried out probabilistic analyses of earthquake hazard for the United States (Frankel and others, 1996; Frankel and others, 2002; Petersen and others, 2008). Probabilistic Seismic Hazard Analysis (PSHA) is a method used to estimate the level of ground motion with a specified probability of exceedance (Cornell, 1968; Reiter, 1990). Earthquakes from all possible regional seismic sources, each with a given probability of occurrence, are taken into account in this type of analysis. This includes gridded seismic sources with probabilities estimated from the Gutenberg-Richter relation (Richter, 1958; Weichert, 1980), valid for observed regional background seismicity, as well as earthquake sources along known faults with estimated recurrence rates. This calculation uses a suite of ground-motion attenuation curves, with associated uncertainties in the ground motion level as a function of magnitude, distance, and spectral period. The hazard estimates from all possible sources and at all distances are summed to create the hazard curves at each site. The ground motion corresponding to a prescribed probability of exceedance is selected from the hazard curves at all sites in the region to make a probabilistic hazard map. The USGS produced national seismic hazard maps for the United States in 1996 (Frankel and others, 1996), with updates in 2002 (Frankel and others, 2002), and most recently in 2008 (Petersen and others, 2008).

The national seismic hazard maps (Petersen and others, 2008) used the following earthquake source data and attenuation relations to describe the hazard in the central and eastern United States. The earthquake occurrence-rate component was based on a catalog of earthquakes with magnitude 3.0 or greater from 1700 through 2006. The size of the largest possible earthquake was $\mathrm{M}_{\mathrm{w}} 6.6$ to 7.2 within the central and eastern parts of the North American continent outside of specific seismic zones such as the Eastern Tennessee, New Madrid, and Wabash Valley seismic zones, and $\mathrm{M}_{\mathrm{w}} 7.1$ to 7.7 for the extended continental margin. The Wabash Valley region was assigned a maximum magnitude of $\mathrm{M}_{\mathrm{w}}$ 7.5. The relatively high maximum magnitude assigned for the Wabash Valley is supported by paleoliquefaction evidence from eight past earthquakes of $\mathrm{M}_{\mathrm{w}}>6.0$ in southern Indiana and Illinois (Wheeler and Cramer, 2002; Olson and others, 2005), including one earthquake near Vincennes about 6100 years ago that may have been as large as $\mathrm{M}_{\mathrm{w}} 7.3$ (Munson and others, 1995; Green and others, 2005; Olson and others, 2005). 
The fault-source component of the seismic hazard in the central and eastern United States (CEUS) was based on four source areas where paleoseismic data constrain recurrence rates: New Madrid, Missouri; Charleston, South Carolina; Meers, Oklahoma; and Cheraw, Colorado. Because of the uncertainty in recurrence rates and earthquake magnitude, several weighted estimates of the seismic hazard were combined using alternative source models. Several cases were considered for the New Madrid source region, which is the closest to and most important of the fault sources for Evansville. This seismic source was considered characteristic, having a single magnitude rather than being exponentially distributed as for Gutenberg-Richter sources. Its magnitude in the alternate source models varied from $\mathrm{M}_{\mathrm{w}} 7.1$ to 8.0 , its recurrence interval from 500 to 1,500 years, and its location varied among 5 possible parallel strands. Clustered and unclustered models were also considered. At a given site, for each possible earthquake location and magnitude determined by the source model, the probability of a given ground motion occurring was calculated based on central and eastern United States attenuation curves. Seven attenuation curves were used that assumed a standard National Earthquake Hazards Reduction Program (NEHRP) B/C site condition (Building Seismic Safety Council, 2004), which implies an average shear-wave velocity of 760 meters per second $(\mathrm{m} / \mathrm{s})$ in the top 30 meters of the soil at a given site. The probabilistic seismic hazard maps accounted for source uncertainties through a logic-tree approach of varying the different source parameters, and accounted for random variations in ground motion using the uncertainty assigned to the attenuation curves. Figure 1 shows for Indiana the calculated peak ground acceleration (PGA) and spectral acceleration (SA) at 0.2-second (s) and 1.0-s periods with 2 percent probability of exceedance (PE) in 50 years from the 2008 USGS national seismic hazard maps. The 2008 national seismic hazard maps have been submitted for consideration in the 2009 NEHRP Recommended Provisions for Seismic Regulations for New Buildings and Other Structures. Further details on the PSHA methodology can be found in the documentation for the national seismic hazard maps and other literature (McGuire, 2004; Petersen and others, 2008).
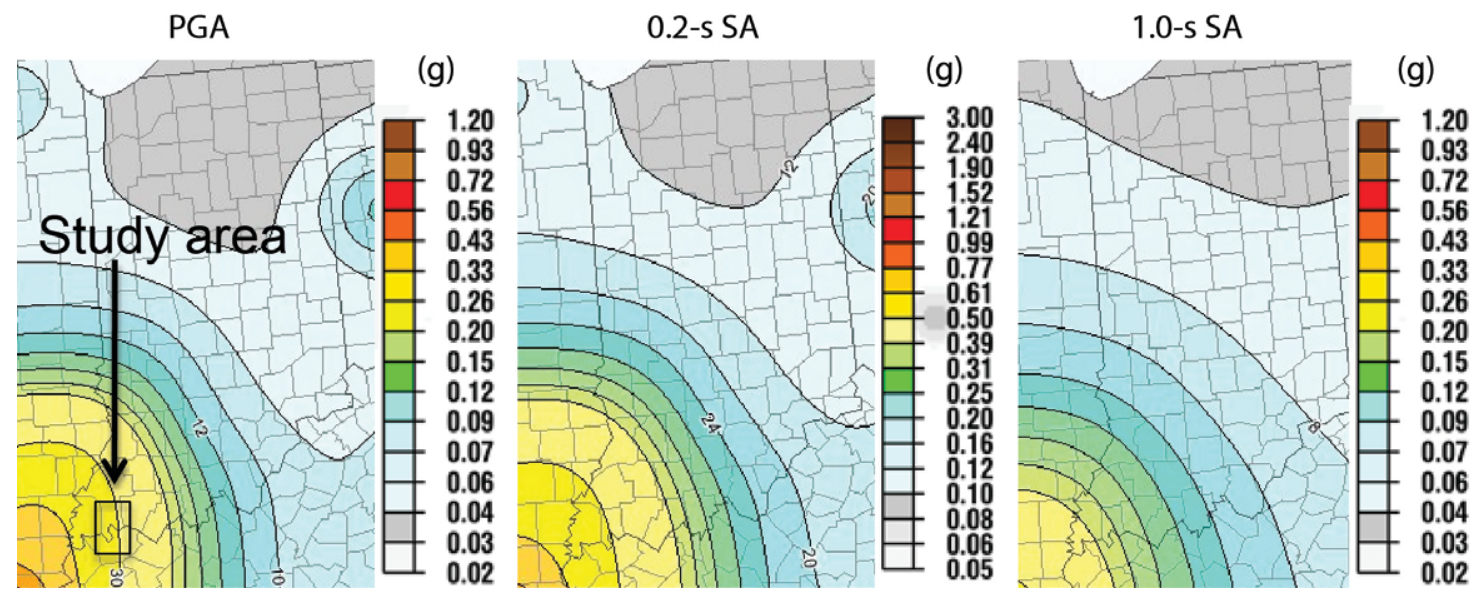

Figure 1. 2008 USGS national seismic hazard map shown for the Indiana region for 2 percent probability of exceedance in 50 years at (left) peak ground acceleration (middle) 0.2 -second (s) spectral acceleration (SA) and (right) 1.0-s SA (Petersen and others, 2008). The maps include by default the site response for a NEHRP B/C site classification. Rectangle in the left map shows the Evansville study region. 
Current USGS probabilistic seismic hazard estimates (Petersen and others, 2008) show higher seismic hazard in southwestern Indiana than for the rest of Indiana, primarily due to the proximity of the New Madrid seismic zone. However, local geology and soil conditions influence the characteristics of ground motion in terms of amplitude, frequency content, and duration (Kramer, 1996). The effect of local site conditions on ground motion is not considered in the USGS national seismic hazard maps, which incorporate as a default a firm rock site response with NEHRP B/C site conditions.

The 2009 NEHRP recommendation for alternative site conditions is to scale the PSHA for B/C site condition using NEHRP factors, which vary somewhat for amplitude of the ground motion. Cramer (2006) has shown that this procedure does not correctly take into account the uncertainties associated with site condition or the actual ground-motion amplitude- and frequency-dependent amplification associated with real soil columns. The objective of this work is to produce a probabilistic seismic hazard map for the ninequadrangle region surrounding Evansville that properly takes into account ground-motion amplification due to near-surface geologic materials that vary considerably. The depositional history of the area includes several periods of glacier advance and retreat leaving behind sequences of till and loess, periods of slackwater lake deposition, and recurring sequences of fluvial deposition and overbank deposits in the Ohio River Valley. These near-surface soils are expected to have a major impact on the ground-motion amplification in the probabilistic seismic hazard calculation.

Section 2 describes the data used to develop a three-dimensional (3D) model for soil properties and bedrock depth necessary for the site effect calculations. Section 3 describes the analysis of the depth-dependent soil properties. Section 4 explains the method used for creating the bedrock elevation model. Section 5 presents the results of soil response sensitivity tests. Section 6 describes the seismic amplification calculated using this 3D model. Section 7 describes the resulting probabilistic seismic hazard maps, and section 8 presents the discussion and conclusions.

\section{Data}

Subsurface information on soil properties is required for the site amplification analysis. Parameters significantly affecting the site response calculation are the shear-wave velocity, soil type, density, thickness and dynamic properties (shear modulus reduction and damping curves) of each of the soil layers above bedrock. Most of these parameters can be determined from field site investigations. Two parameters, the bedrock depth and shearwave velocity of soil layers, are the most important in terms of determining the seismic amplitude. Because it is not feasible to collect data at all points in the study region, several reference models are developed from the observed data. The geologic map provides a context for generalizing incomplete and sparse geophysical data. This study takes advantage of recent 1:50,000-scale surface geologic mapping, and a compilation of new and existing subsurface test data to develop such a model.

\section{Geologic Setting and Map}

The surficial geology along the Ohio River valley near Evansville consists of a variety of glacial and interglacial lithologic sequences characterized by a series of fluvial and lake depositional events, in which relatively thick Ohio River fluvial deposits backed 
up tributary streams to form lakes (Eggert and others, 1996; 1997a; b). The geologic maps are used to associate regions with similar depositional history and similar properties to representative shear-wave velocity profiles. The geologic mapping was carried out through a collaboration called the Evansville Area Earthquake Hazards Mapping Project, with contributions from the Indiana Geological Survey (IGS), Kentucky Geological Survey (KGS), and USGS (figure 2). The surficial geology was mapped in 24 different units at the 1:50,000 scale for 7.5 of the 9 quadrangles in the study region (Moore and others, 2009). Although not all of these units are distinct seismically, they provide a context for generalizing seismic properties for a simplified model. 


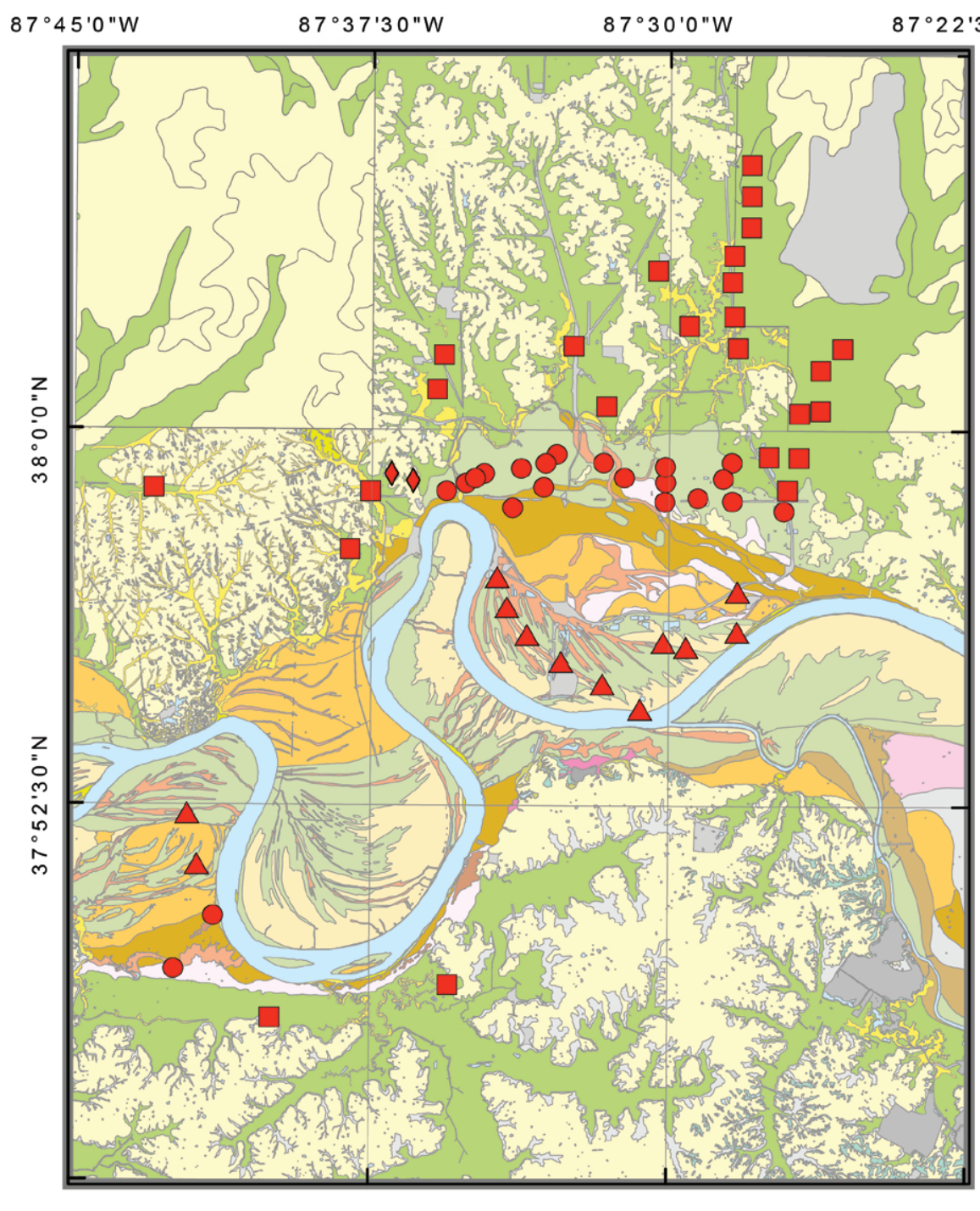

EXPLANATION

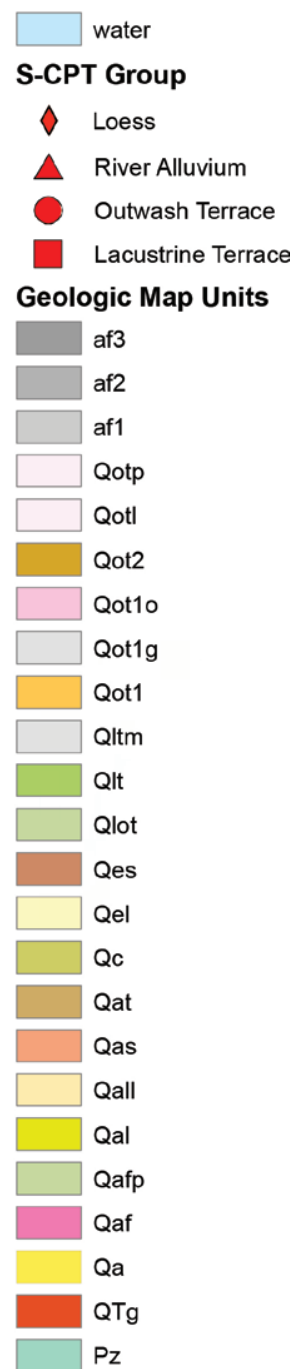

Figure 2. Merged surficial geologic map from the 1:50,000- (Moore and others, 2009) and 1:500,000- (Gray, 1989) scale maps including cone-penetrometer test sites with shear wave measurements (red symbols). Mapped units are Quaternary: Qc, colluvium; Qal, alluvium; Qall, levee deposit alluvium; Qas, alluvium in modern flood plain sloughs; Qaf, alluvium in alluvial fans; Qafp, river flood plain alluvium; Qat, low terrace alluvium; Qa, creek and sheetwash alluvium; Qes, dune sand; Qel, loess; Qot1o, reworked Ohio River terrace outwash alluvium; Qot1g, reworked Green River terrace alluvium; Qltm, upland marginal lacustrine deposits; Qlt, lacustrine terrace slackwater deposits; Qot1, low terrace outwash alluvium; Qlot, lacustrine and outwash terrace deposits; Qotp, paleolevee deposits on outwash terrace; Qot2, high terrace outwash alluvium; QTg, Quaternary and Tertiary upland gravel; Pz, Paleozoic bedrock; af1, af2, af3, modern artificial fill. Red symbols indicate cone-penetrometer test sites with shear-wave measurements. Red triangles are in group 1 (River alluvium group-includes recent and old Ohio River sediments mapped as surficial map units Qaf, Qafp, Qal, Qall, Qas, Qat, Qot1, Qot1g, Qot10), red circles are in group 2 (Outwash terrace group-includes Qlot, Qot2, Qotp), red squares are in group 3 (Lacustrine terrace group -includes Qlt, Qa, Qltm), and red diamonds are in group 4 (Loess and colluvium group-includes Qel, Qc). 
For the northwest quadrangle and half of the northeast quadrangle, the most recently available Quaternary geologic map at 1:500,000 scale was used (Gray, 1989). In these quadrangles, the lower resolution is not critical since much of these two quadrangles is either strip mined or consists of bedrock covered by thin loess, which is of less concern in seismic shaking calculations, and the few alluvial units are reasonably well represented, even with this lower resolution. The geologic units of the two different scales of mapping were correlated and the unit designations were taken from the 1:50,000-scale maps.

\section{Subsurface Data}

The available subsurface geotechnical datasets inside the nine-quadrangle area include water-well logs, in-situ soil profiles using the cone penetration test with shear wave measurements (S-CPT) and standard penetration test (SPT), down-hole shear-wave velocity tests, and seismic refraction tests (table 1). On the Indiana side of the Ohio River, 52 S-CPT profiles were measured and on the Kentucky side 6 S-CPT profiles were measured (Holzer, 2003). These S-CPT measurements contain tip resistance, sleeve friction, and shear-wave travel time, and extend to approximately $20 \mathrm{~m}$ for the majority of the profiles. Shear-wave velocity and soil type were inferred from these measurements. Compiled by the IGS were 570 SPT blow count profiles and soil description logs at 59 geotechnical boring sites [Choi and Hill, 2005, written communication]. The blow count data were used to calculate shear-wave velocity for comparison at point locations for verifying the reference model, and provided shallow bedrock depth information, which was incorporated into the bedrock surface model. Also compiled were 26 borehole shear-wave velocity profiles from down-hole tests and soil type logs (Eggert and others, 1994). In addition, the IGS database of 228 P-wave refraction profiles (Rudman and others, 1973) was used to provide observations of bedrock depth. A series of 15 shear-wave refraction profiles (Bauer and CUSEC State Geologists, 2005) in and around Evansville provide checks on the characteristic velocities for the soil types. The IGS iLITH database of 827 water-well logs provided additional data on the bedrock depth and provided information on the soil type profile with depth (Bleuer, 2000). Available on the Kentucky side of the Ohio River as well are 583 bedrock elevations from KGS coal, oil, gas, and water well logs (Ron Counts, KGS, personal communication, 2005). The locations of all the subsurface data are shown in figure 3.

Table 1. Descriptions of subsurface observations available in the Evansville region.

\begin{tabular}{|l|l|}
\hline \multicolumn{1}{|c|}{ Data type } & \multicolumn{1}{c|}{ Reference } \\
\hline \hline 58 S-CPT profile data collected by the USGS & (Holzer, 2003) \\
\hline 26 borehole shear-wave velocity profiles & (Eggert and others, 1994) \\
\hline 570 SPT blow count data at 59 geotechnical boring sites & $\begin{array}{l}\text { (Y.-S. Choi and J. Hill, personal } \\
\text { communication 2005) }\end{array}$ \\
\hline 228 P-wave seismic refraction profiles & (Rudman and others, 1973) \\
\hline 15 nearby shear-wave refraction profiles & (Bauer and CUSEC State Geologists, 2005) \\
\hline $\begin{array}{l}\text { Indiana Geological Survey iLITH GIS database of } \\
\text { approximately 827 water well logs }\end{array}$ & (Bleuer, 2000) \\
\hline 583 Kentucky Geological Survey oil, gas, water well logs & (R. Counts, personal communication, 2005) \\
\hline
\end{tabular}




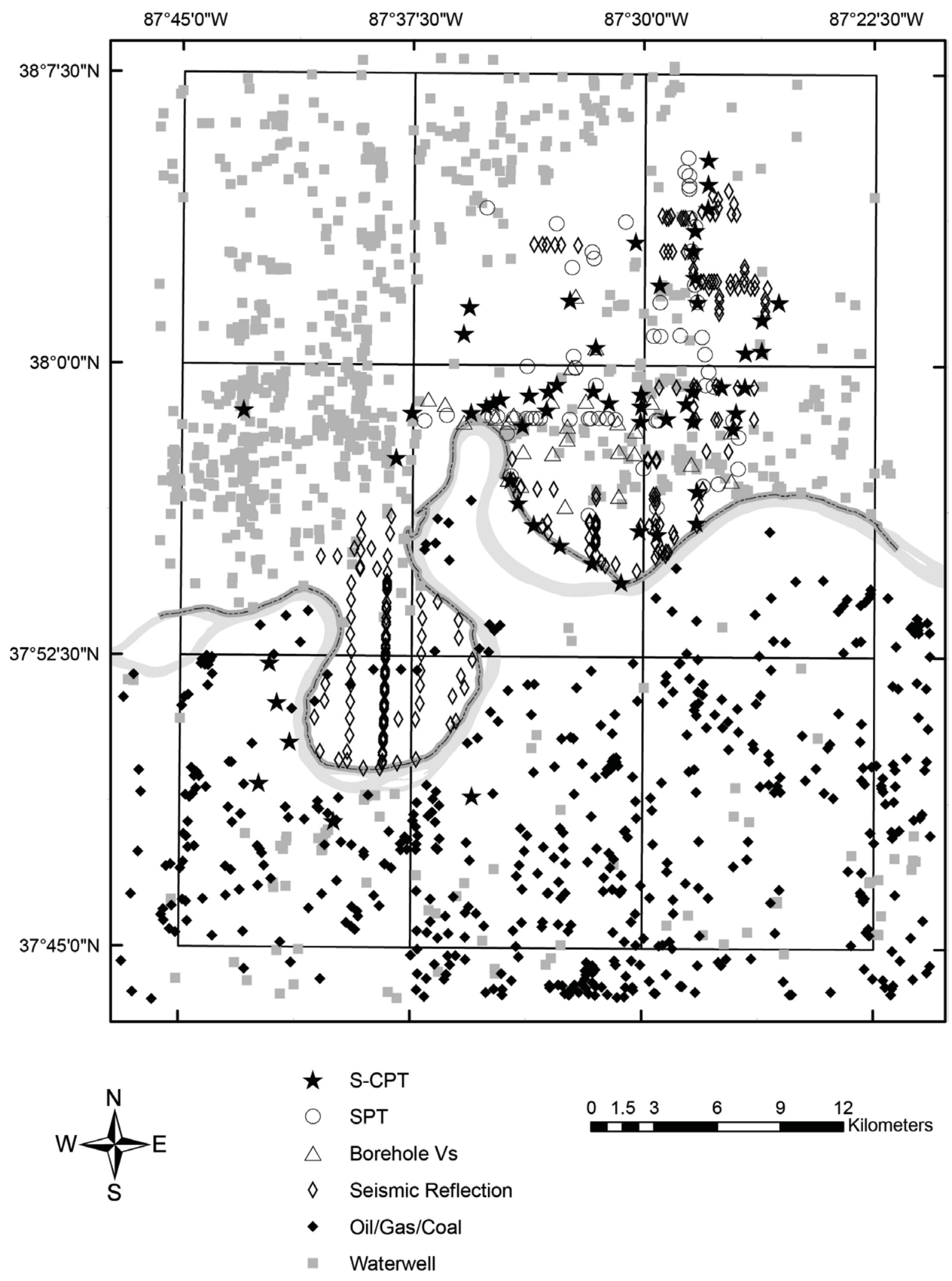

Figure 3. Locations of subsurface observations available in the Evansville region. 


\section{Analysis of Local Geology and S-CPT Soil Profile Data}

The S-CPT data is the primary dataset used to classify the shallow shear-wave velocity of soils within the study area surrounding Evansville. The S-CPT data (figure 4) show distinctively different characteristics in the soil property profiles depending on their geomorphic or geologic setting. The correlation between shear-wave velocity and soil type is examined for S-CPT profiles located within each surficial geologic map unit. The S-CPT profiles are found to be similar with depth within geologic map units that are considered terrace deposits and mixed overbank with interfingered lacustrine deposits (upper left profiles in figure 4). The geologic units described as predominantly river alluvium in the flood plain (lower left profiles in figure 4) have different soil types with depth than the terrace deposits, however their seismic velocity characteristics are quite similar when considered as a whole. The S-CPT profiles that are located within lacustrine surficial geologic map units have clay as the dominant soil type as shown on the upper and lower right in figure 4 . There are only two sites available located within the geologic map units that are described as loess and colluvium. Thus, we distinguish four groups of geologic map units, and refer to these characteristic profiles as the river alluvium, outwash terrace, lacustrine terrace, and loess profiles.

For each group, the average shear-wave velocity was calculated in 2-meter (m) intervals over each available S-CPT profile belonging to the group. The depth-dependent average velocity and the standard deviation of the velocity at each depth for the four groups are shown in figure 5 and listed in table 2.

Table 2. Depth-dependent average shear-wave velocities for the river alluvium, outwash terrace, lacustrine terrace and loess groups. Depth to the top of the layer is given. $(\sigma$, standard deviation, $\mathrm{m}$, meters, $\mathrm{m} / \mathrm{s}$, meters per second)

\begin{tabular}{|c|c|c|c|c|c|c|c|c|c|c|c|}
\hline \multicolumn{3}{|c|}{ River alluvium group } & \multicolumn{3}{|c|}{ Outwash terrace group } & \multicolumn{3}{|c|}{ Lacustrine terrace group } & \multicolumn{3}{|c|}{ Loess and colluvium group } \\
\hline $\begin{array}{l}\text { Depth } \\
\text { (m) }\end{array}$ & $\begin{array}{c}\text { Shear- } \\
\text { velocity } \\
(\mathrm{m} / \mathrm{s})\end{array}$ & $\begin{array}{c}\sigma \\
(\mathrm{m} / \mathrm{s})\end{array}$ & $\begin{array}{l}\text { Depth } \\
\text { (m) }\end{array}$ & $\begin{array}{c}\text { Shear- } \\
\text { velocity } \\
(\mathrm{m} / \mathrm{s})\end{array}$ & $\begin{array}{c}\sigma \\
(\mathrm{m} / \mathrm{s})\end{array}$ & $\begin{array}{c}\text { Depth } \\
\text { (m) }\end{array}$ & $\begin{array}{c}\text { Shear- } \\
\text { velocity } \\
(\mathrm{m} / \mathrm{s})\end{array}$ & $\begin{array}{c}\sigma \\
(\mathrm{m} / \mathrm{s})\end{array}$ & $\begin{array}{c}\text { Depth } \\
\text { (m) }\end{array}$ & $\begin{array}{c}\text { Shear- } \\
\text { velocity } \\
(\mathrm{m} / \mathrm{s})\end{array}$ & $\begin{array}{c}\sigma \\
(\mathrm{m} / \mathrm{s})\end{array}$ \\
\hline 0.00 & 196.6 & 39.2 & 0.00 & 163.9 & 24.1 & 0.00 & 155.7 & 23.1 & 0.00 & 117.4 & 33.1 \\
\hline 1.75 & 216.9 & 51.5 & 1.75 & 196.8 & 28.9 & 1.75 & 168.5 & 20.5 & 1.75 & 141.7 & 60.4 \\
\hline 3.75 & 202.6 & 44.5 & 3.75 & 216.7 & 42.7 & 3.75 & 184.5 & 16.0 & 3.75 & 196.0 & 53.1 \\
\hline 5.75 & 187.2 & 26.9 & 5.75 & 225.7 & 32.9 & 5.75 & 202.4 & 22.3 & 5.75 & 223.6 & 57.5 \\
\hline 7.75 & 199.7 & 25.7 & 7.75 & 230.0 & 29.9 & 7.75 & 217.0 & 19.0 & 7.75 & 246.4 & 70.2 \\
\hline 9.75 & 218.2 & 34.8 & 9.75 & 244.4 & 33.7 & 9.75 & 237.8 & 29.6 & 9.75 & 267.9 & 73.8 \\
\hline 11.75 & 231.5 & 21.5 & 11.75 & 246.0 & 26.4 & 11.75 & 238.4 & 32.6 & 11.75 & 277.9 & 64.2 \\
\hline 13.75 & 257.8 & 31.2 & 13.75 & 255.4 & 21.0 & 13.75 & 232.0 & 29.2 & 60.00 & 1251.1 & 283.5 \\
\hline 15.75 & 277.0 & 39.5 & 15.75 & 251.9 & 18.4 & 15.75 & 263.3 & 49.2 & & & \\
\hline 17.75 & 286.5 & 38.0 & 17.75 & 262.7 & 22.1 & 17.75 & 282.0 & 53.4 & & & \\
\hline 19.75 & 301.1 & 88.7 & 19.75 & 301.1 & 88.7 & 19.75 & 301.1 & 88.7 & & & \\
\hline 23.75 & 316.5 & 84.7 & 23.75 & 316.5 & 84.7 & 23.75 & 316.5 & 84.7 & & & \\
\hline 27.75 & 297.0 & 73.9 & 27.75 & 297.0 & 73.9 & 27.75 & 297.0 & 73.9 & & & \\
\hline 31.75 & 320.2 & 112.5 & 31.75 & 320.2 & 112.5 & 60.00 & 1251.1 & 283.5 & & & \\
\hline 35.75 & 373.2 & 59.1 & 35.75 & 373.2 & 59.1 & & & & & & \\
\hline 39.00 & 541.6 & 73.6 & 39.75 & 541.6 & 73.6 & & & & & & \\
\hline 60.00 & 1251.1 & 283.5 & 60.00 & 1251.1 & 283.5 & & & & & & \\
\hline
\end{tabular}




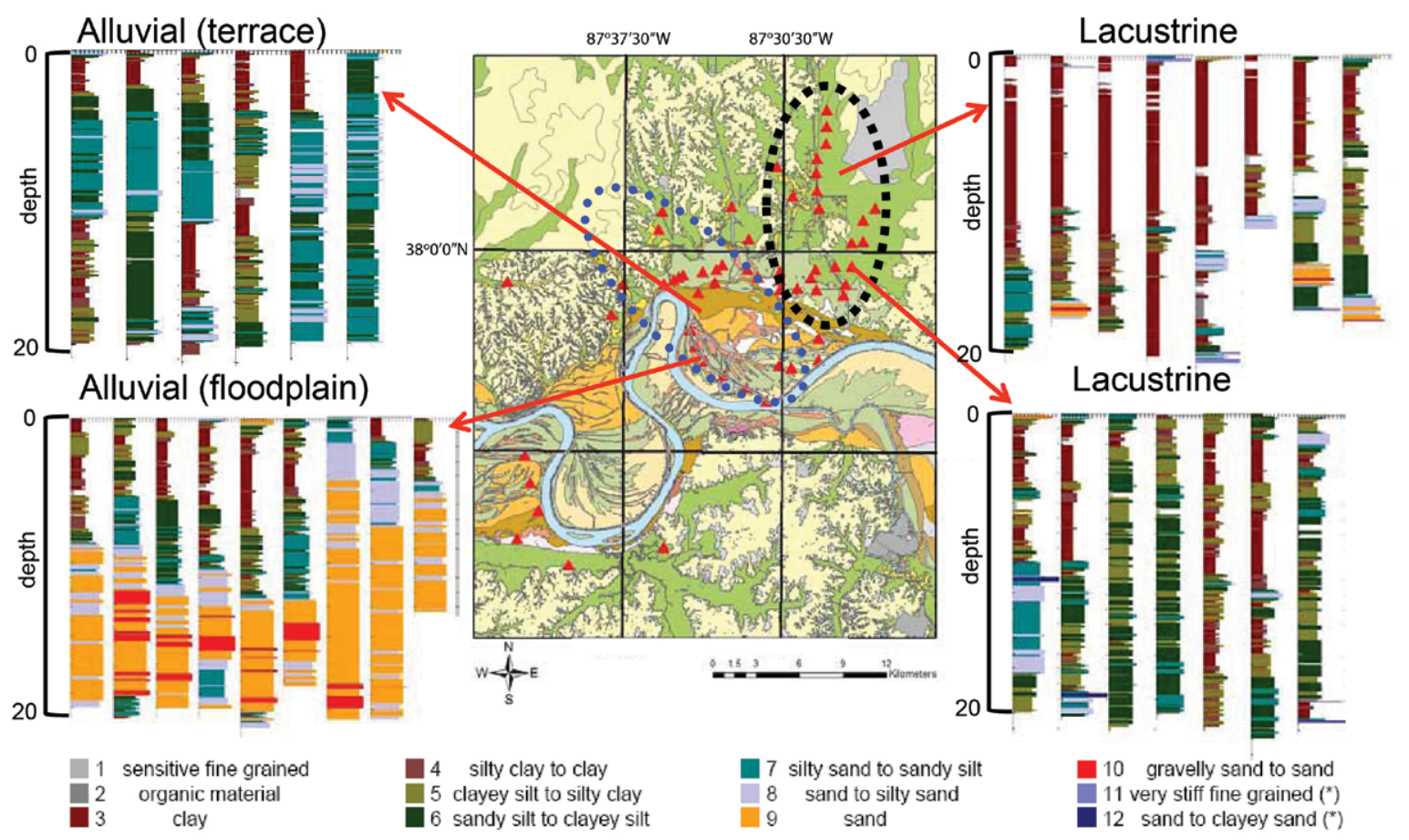

Figure 4. Examples of soil-type profiles from the S-CPT data from the outwash terrace alluvium, flood plain river alluvium, and lacustrine terrace environments [profiles are modified from (Holzer, 2003)]. Ovals show the profile locations included in each group.
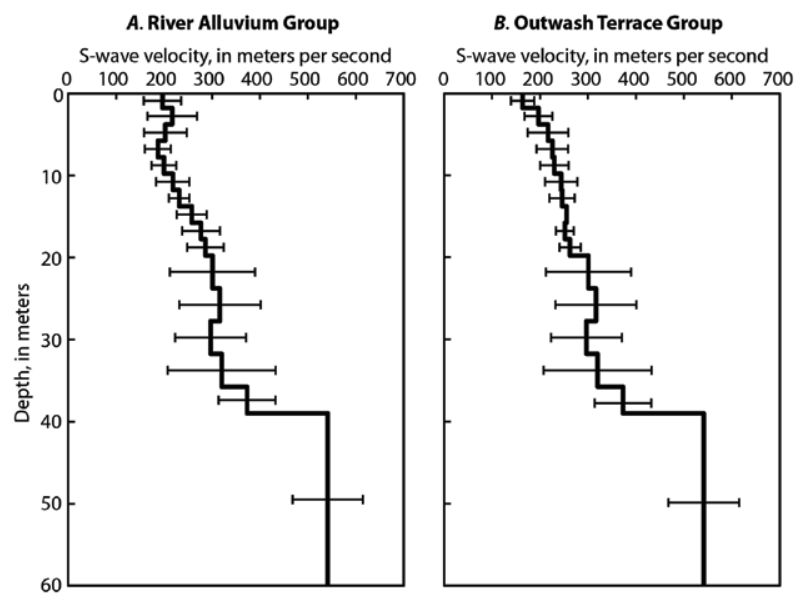

C. Lacustrine Terrace Group S-wave velocity, in meters per second

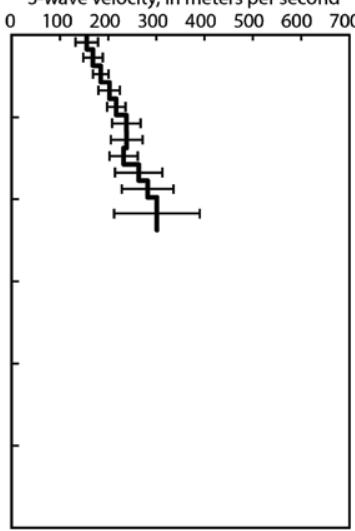

D. Loess and Colluvium Group

S-wave velocity, in meters per second

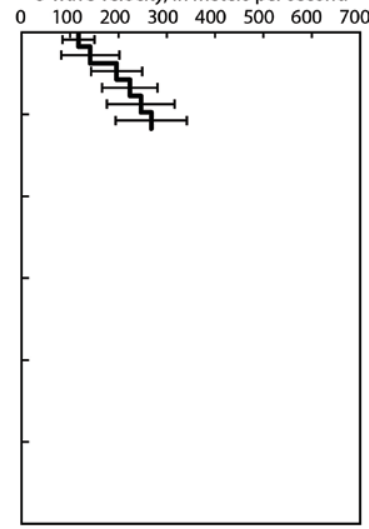

Figure 5. Depth-dependent soil average shear-wave velocity models for (left) river alluvium, (center-left) outwash terrace, (center-right) lacustrine terrace, and (right) loess groups determined from the S-CPT profiles. The last measured velocity is extrapolated to the bedrock depth. Error bars show 1 standard deviation. 
At depths to $20 \mathrm{~m}$ the averages are constrained by at least 33 profiles. Used to determine a relation for depth-dependent velocity below the S-CPT profiles from 20 to 30 $\mathrm{m}$ depth were 26 borehole shear-wave velocity profiles (Eggert and others, 1994), and this velocity was extrapolated to $60 \mathrm{~m}$. The standard deviation for the entire dataset of the differences between the individual layer velocity at a given depth and the average layer velocity at that depth is $63.9 \mathrm{~m} / \mathrm{s}$.

In the depth range above $20 \mathrm{~m}$, the borehole shear-wave velocity profiles were used only to evaluate the final accuracy of the reference models. Based on the surficial geologic map unit at the location of the borehole measurement, the river alluvium, outwash terrace, lacustrine terrace, or loess type of velocity profile was assigned. The differences between the reference model velocity and the borehole velocity observations at each depth were then calculated. The standard deviation of those differences is $59.3 \mathrm{~m} / \mathrm{s}$, which is close to the $63.9 \mathrm{~m} / \mathrm{s}$ accuracy estimate from our analysis of the original S-CPT dataset. This demonstrates that the model is reliable as a predictive tool. It also provides an independently derived error estimate for the velocity. The uncertainty is as important as the velocity value, because it is used to infer the range of variations in the site amplification analysis.

For comparison, the accuracy of other simple models created using the S-CPT dataset was also evaluated. For example, we tested a depth-dependent reference velocity model that is simply an average of the S-CPT values at each layer depth from all S-CPT profiles combined, regardless of the geomorphic setting. For each borehole velocity profile location, the difference between the observed borehole velocity and the simple depthdependent model was calculated. In this case the standard deviation of the differences for the whole dataset is $74.5 \mathrm{~m} / \mathrm{s}$. Not surprisingly, this gives a rather poorer fit. Another model was tested that assigns a different velocity to each of the three predominant soil types (clay, sand, and silt) as a function of depth irrespective of their depositional environment and geographic location. This model yields a standard deviation of $75.9 \mathrm{~m} / \mathrm{s}$. A model where a single average $V_{s}$ value is calculated for all the data within each surficial geologic unit, has the poorest predictive capability of all. Compared to these three alternatives, our depthdependent model which is assigned based on the surficial geologic unit given in table 2 fits the data well, and the uncertainties in the velocities have been carefully characterized, which allows a robust probabilistic calculation. Each grid point in the study area is then assigned one of the velocity profiles based on its geomorphic setting. This yields the geographic distribution of velocity profiles shown in figure 6 . 


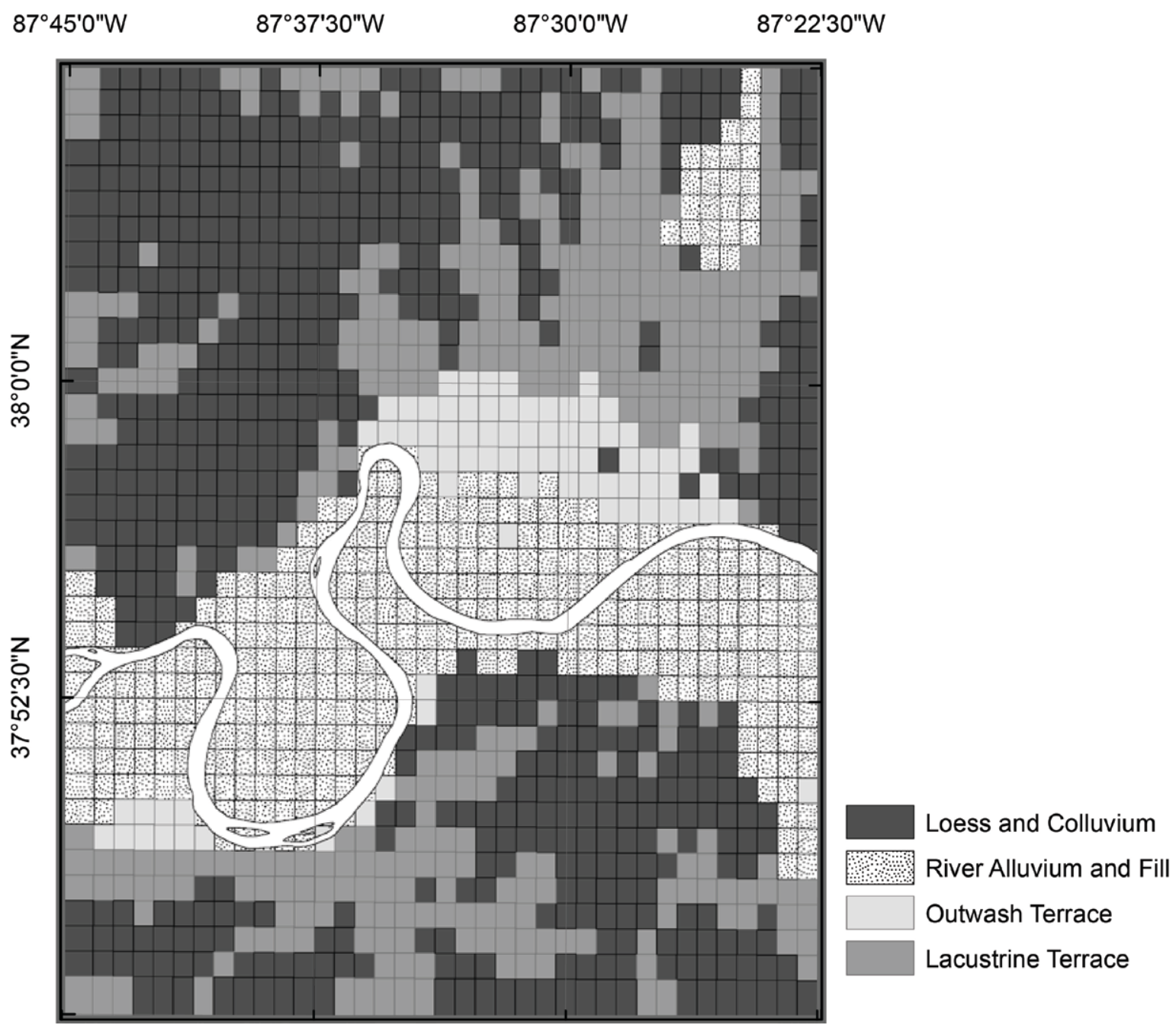

Figure 6. Assignment of velocity profile characteristics at $1 \mathrm{~km}$ grid cell size. Note that the velocity depends on depth within regions shown as a single color.

\section{Bedrock Elevation}

Development of a detailed model for bedrock elevation based on all available data is required to calculate the site response. Bedrock elevation would ordinarily be determined either directly by observation or indirectly by the relation between surface elevation and a bedrock depth model. Previously existing bedrock elevation contours at 1:500,000 scale (Gray, 1983) are not detailed enough to capture smaller scale soil thickness variability, which has a strong influence on site amplification. Accordingly, several procedures were used to generate a bedrock elevation model.

Within the study area, we have compiled 900 IGS water well logs from the iLITH database (Bleuer, 2000), 230 bedrock depth measurements interpreted from P-wave refraction profiles (Rudman and others, 1973; Whaley and others, 2002), and bedrock elevation points from KGS oil, gas, and water well logs to develop a model for the bedrock depth. IGS water well logs contain information on the surface elevation, bedrock elevation and bedrock depth. The KGS data also contain qualitative estimates of uncertainty, from 
$0.3 \mathrm{~m}$ to $4 \mathrm{~m}$. For points where bedrock elevation was not included in the data set, the bedrock elevation was calculated by subtracting the bedrock depth from the USGS 1 arcsecond digital elevation model (DEM) raster value at the point location (U.S. Geological Survey, 2004). Points were included within $5 \mathrm{~km}$ outside of the 9-quadrangle area of interest to avoid edge effects in the interpolation at the boundary of the project area.

Several steps were combined in the process to interpolate the point data to construct an optimal gridded bedrock depth model. The uplands within the study area are primarily loess-covered bedrock. As the loess was deposited, it formed a blanket of eolian silt and fine sand that gradually increases in thickness from approximately $2 \mathrm{~m}$ in the northeastern section of the study region to $8 \mathrm{~m}$ towards the southwest. Because the loess surface mimics the bedrock surface, the method for interpolation in the uplands is best implemented by having the bedrock surface roughly parallel the ground surface rather than estimate a bedrock elevation from widely scattered boreholes in an area of relatively high relief.

In the lowlands regions, however, where the current-day surface topography is not directly dependent on the bedrock elevation, it is better to smoothly interpolate the bedrock elevation data points so that the complexity of the bedrock surface realistically reflects the resolution of the data density.

Here is provided more background on the additional steps involved in this process. Detailed bedrock elevation contours were produced for the region south of the Ohio River (D. Andrews, KGS, written communication), which were based on a similar point data set to that which was described above. The basic method used to construct that part of the map was (1) thickness contours were drawn based on loess thickness within all geologic map units containing loess and based on areas of exposed bedrock; (2) in the outwash and alluvium areas of the Ohio River Valley, hand contoured bedrock elevations were based on information from earlier low resolution bedrock maps with the addition of the higher quality oil, gas and water-well data; (3) in tributary valleys, hand contoured bedrock elevations were based on well data and seismic data that delineated the shape of underlying steep-sided U-shaped bedrock valleys.

The same approach was approximated on the north side of the Ohio River. Here, we used kriging on the bedrock depth point data to produce contours of bedrock depth in the loess-covered uplands. Local interpolation and co-kriging on bedrock depth and elevation produced contours of bedrock elevation in the lowland areas.

For the uplands, the contour products from the Indiana and Kentucky uplands models were merged and a bedrock surface raster that optimized hydrological continuity was created, applying a strict (2-sigma) constraint to fit a subset of the highest quality data points. For the lowlands, the lowlands model from the bedrock elevation interpolation was used to create a hydrologically optimized bedrock surface raster using a more relaxed $3 \mathrm{~m}$ misfit constraint on the point data. These two uplands and lowlands rasters were merged, with the uplands model being selected for bedrock elevations above $110 \mathrm{~m}$ above sea level (ASL) and the lowlands model selected below $110 \mathrm{~m}$ ASL. A final quality check was applied to assure outcropping bedrock was accurately represented at the surface. The resulting bedrock depth map and bedrock elevation map are shown in figure 7 . The perspective view shown in figure 8 gives a good representation of the horizontal variability of the individual point measurements, and illustrates the difference in model surface complexity imposed for the uplands and lowlands. 

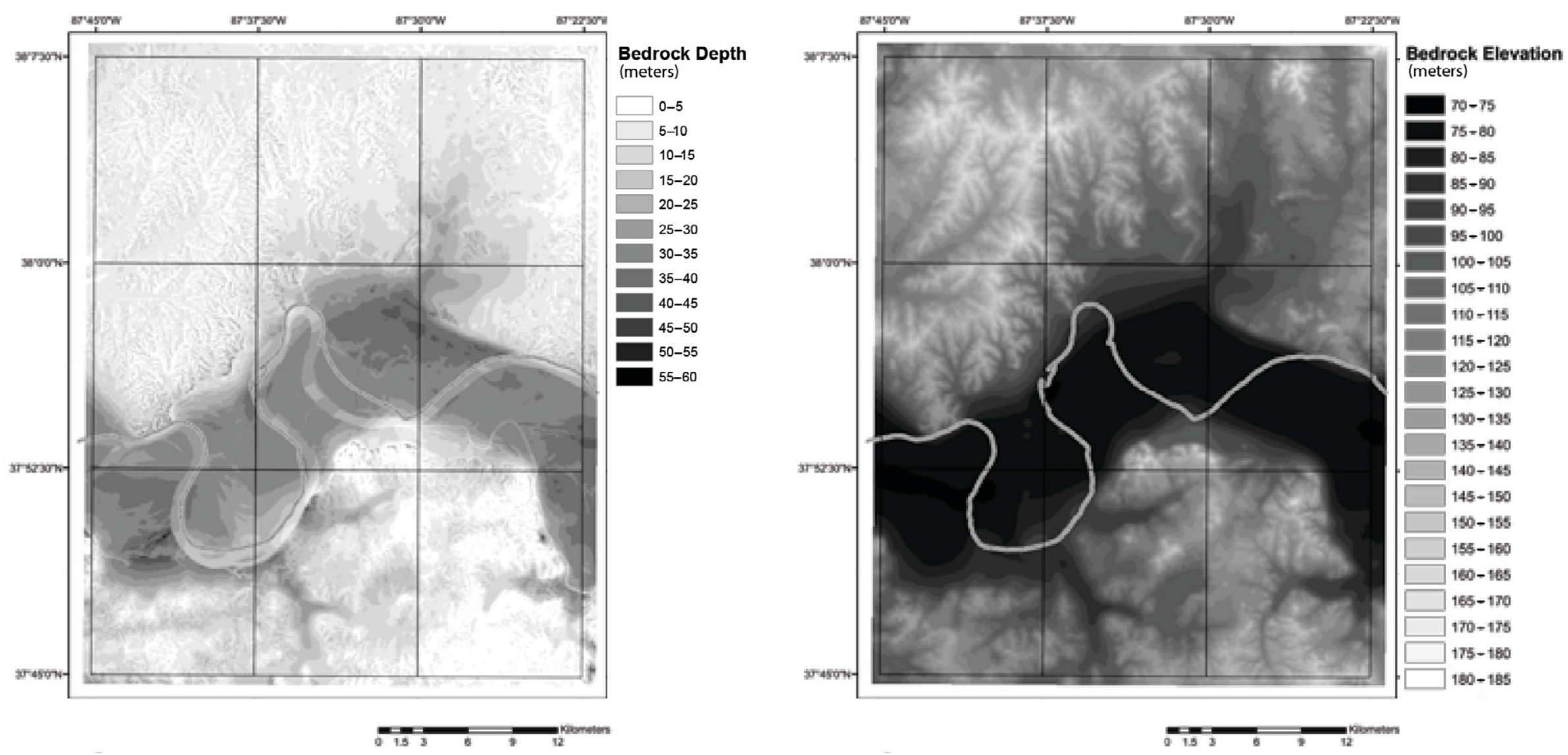

Figure 7. Left: Contoured bedrock depth $(\mathrm{m})$. Right: contoured bedrock elevation ( $\mathrm{m} \mathrm{ASL}$ ). The steep-sided ancient bedrock valley is evident in both maps beneath the flood plain of the present-day meandering Ohio River. 

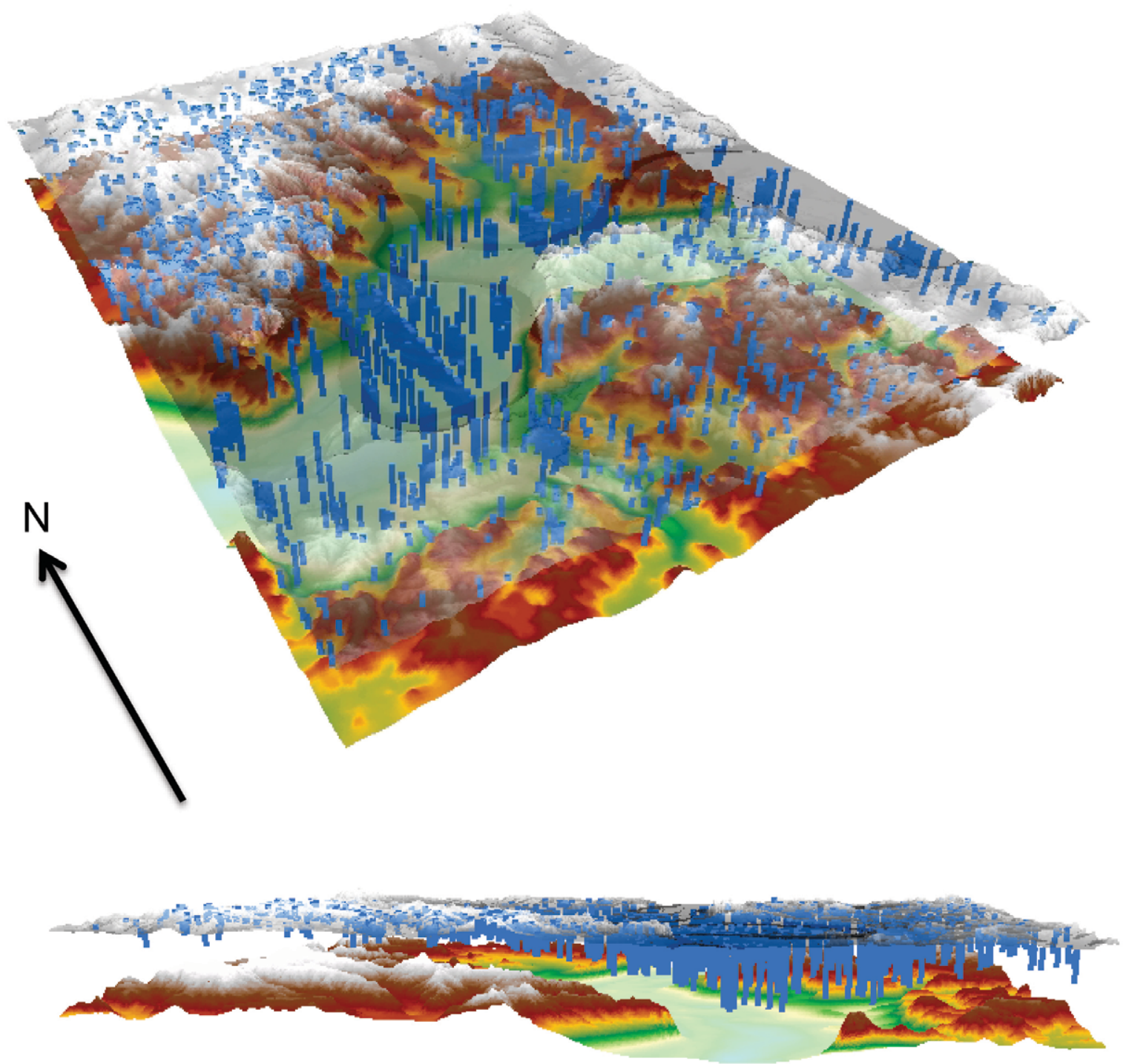

Figure 8. Perspective views of the surface digital elevation model (DEM) (20x vertical exaggeration), depth measurements (blue bars with 20x exaggeration), and derived bedrock elevation (35x exaggeration), with 250 m of offset separating the two surfaces for visibility. Note the difference in density of the uplands point measurements and the lowlands point measurements, and the horizontal variability in their depth.

The bedrock depth is greatest within the ancient bedrock valley underlying the current Ohio River flood plain, which is categorized at the surface as different types of alluvium and outwash deposits on the geologic map (figure 2). The bedrock valley depth is as great as $50 \mathrm{~m}$ close to the Ohio River, with steep valley walls. In contrast, bedrock depth in the northern and southern upland areas is relatively shallow, reflecting the varying thickness of overlying loess. 


\section{Soil Response Sensitivity Tests}

The variation of soil thickness influences the fundamental resonant frequency (and hence, the frequency-dependent soil amplification) of sites within the study area. We tested the sensitivity of the seismic response to different model approximations of the soil profile variation with depth. The amplification factor is calculated using a one-dimensional frequency domain approach assuming shear waves incident on the bedrock/soil interface propagating vertically in a one-dimensionally varying medium (SHAKE91; Idriss and Sun, 1992). The code takes into account nonlinear behavior of the soil column using an iterative equivalent linear method and has been modified to double the standard precision of the calculations so that soil response is properly calculated at high levels of ground motion above 0.2 times the acceleration of gravity ( $\mathrm{g}$ ) to $0.3 \mathrm{~g}$ (Cramer, 2006).

To fully capture uncertainty in site amplification sensitivity tests, 16 different input ground motion time histories, which come from the PEER strong ground-motion database (Pacific Earthquake Engineering Research Center, 2009) (table 3), were used. These events were also used to calculate seismic amplification for the study region.

Table 3. Suite of input bedrock ground motion time histories used in site response calculation.

\begin{tabular}{|l|l|l|l|l|}
\hline \multicolumn{1}{|c|}{ Event } & \multicolumn{1}{c|}{ Date } & M & \multicolumn{1}{c|}{ Site } & Components \\
\hline $\begin{array}{l}\text { Cape } \\
\text { Mendocino }\end{array}$ & $1992-04-25$ & 7.0 & CPM (CDMG 89005) Cape Mendocino & N, E \\
\hline Kobe & $1995-01-16$ & 6.9 & KJMA & N, E \\
\hline Landers & $1992-06-28$ & 7.3 & JOS Joshua Tree & N, E \\
\hline Duzce & $1999-11-12$ & 7.1 & 1060 & N, E \\
\hline Kocaeli & $1999-08-17$ & 7.4 & GBZ & W \\
\hline Kocaeli & $1999-08-17$ & 7.4 & IZT & S \\
\hline Loma Prieta & $1989-10-18$ & 6.9 & 47379 Gilroy Array \#1 & N, E \\
\hline Chi Chi & $1999-09-20$ & 7.6 & TCU046 & horizontal \\
\hline Simulated* & & 7.5 & & horizontal \\
\hline Simulated* & & 8.0 & & \\
\hline
\end{tabular}

* (Beresnev and Atkinson, 2002)

The response from the depth-dependent reference model for the alluvial group from table 2 was compared to several of the individual CPT profiles that are included in this group (VHC018 and VHC020). Figure 9 shows the spectral response calculated for each profile with two different input ground motions: the CPM000 time history (left) and the IZT180 time history (right). The input ground motions were scaled to $0.001 \mathrm{~g}, 0.01 \mathrm{~g}, 0.1$ $\mathrm{g}$, and $1.0 \mathrm{~g}$ in peak ground acceleration (PGA) as annotated, and then the response was normalized by the scaled input. The response for each profile is quite similar in both amplitude and period for the $0.001 \mathrm{~g}$ input ground motion level. Large differences in amplitude for the CPM000 ground motion compared to the IZT180 ground motion illustrate why it is important to use several ground motion time histories to evaluate site response. The normalized response decreases in amplitude as the input ground motion level increases. This deamplification is expected from the nonlinear response of the soils at large ground motions because of damping. There are larger differences among the responses for the different CPT profiles for the input ground motion levels of $1.0 \mathrm{~g}$ and $0.1 \mathrm{~g}$ shown in figure 9, compared to lower ground motions levels. 

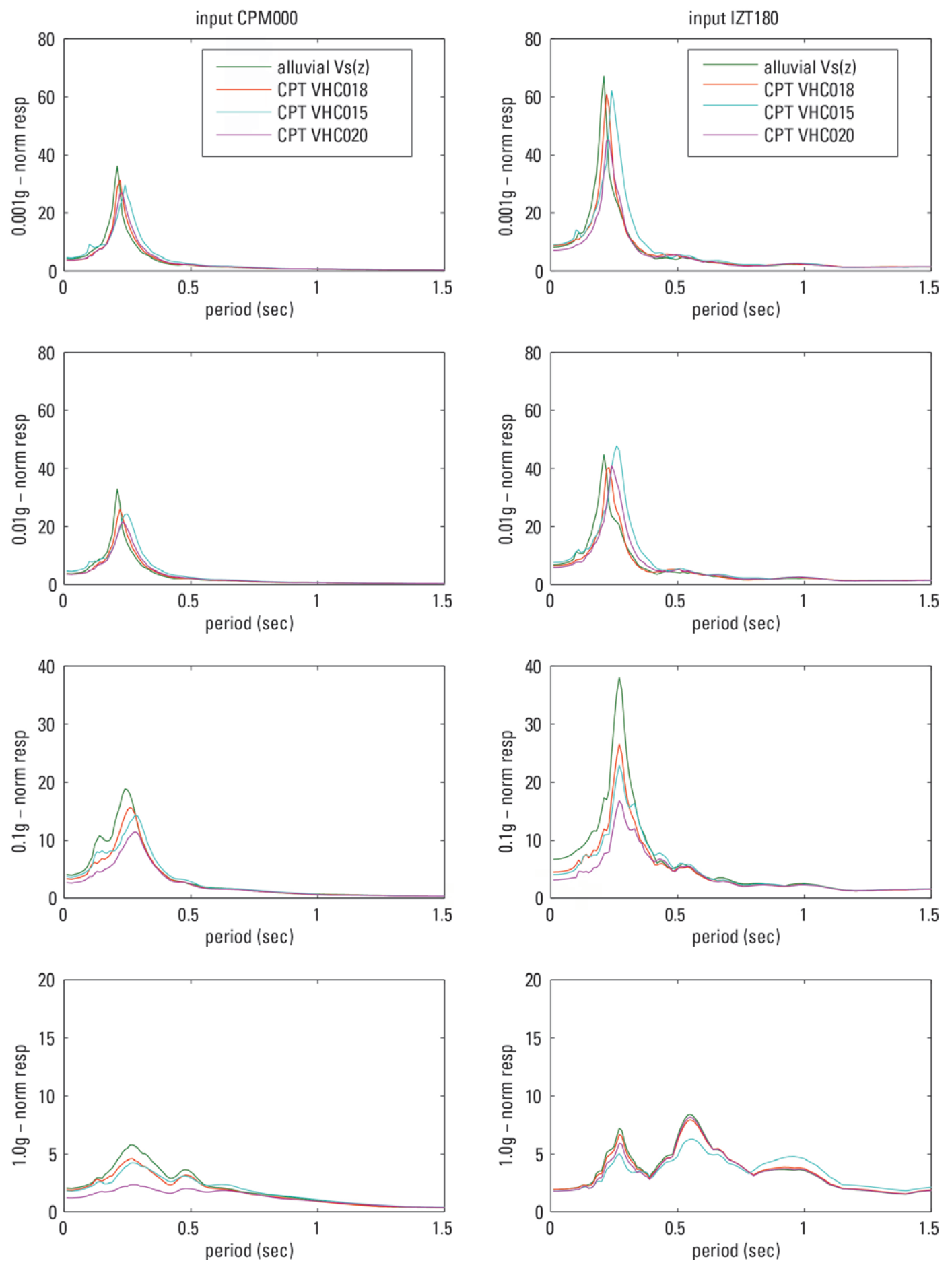

Figure 9. Comparison of normalized spectral response from the alluvial group depth-dependent model and three CPT profiles from within the region assigned to the alluvial group. The responses shown in the left column were calculated with the CPM000 ground motion record and the responses shown in the right column were calculated with the IZT180 ground motion as input. The input ground motion was scaled to PGA values of $0.001 \mathrm{~g}, 0.01 \mathrm{~g}, 0.1 \mathrm{~g}$ or $1.0 \mathrm{~g}$ as annotated. 
It is important to note that the sensitivity of the response to variations in the soil profiles among the 4 profiles tested (depth dependent and three CPT profiles) is low compared to the sensitivity of the response to the input ground motion record. This is illustrated in figure 10, which shows the range of the spectral response for all 16 ground motion time histories. For input ground motion levels less than $0.1 \mathrm{~g}$ PGA, the resonant period is stable for all ground motion time histories, however, the amplitude of the response varies greatly at the resonant period. This reinforces the importance of quantifying the variability in the response by using a suite of ground motions rather than a single time series.

The uncertainty in site response is quantified in the calculation of the amplification from the 3D depth/velocity model for the hazard calculation, where the input ground motion for each of 100 simulations is selected randomly from the suite of 16 time histories. The amplifications in figure 10 show much more variation as a function of period for input ground motion levels of 0.1 and $1.0 \mathrm{~g}$ in PGA.

Significantly, these examples also show that the depth-dependent reference velocity model yields a similar response to those of the measured S-CPT profiles. Similar results were obtained for the lacustrine and loess groups. It is of note that the responses are quite similar for the different velocity model representations for the alluvial groups primarily because there is not a large range of model velocities compared to the uncertainty range for each of the reference models, nor is there a large difference in velocities across all three reference models, for example, for the alluvial, lacustrine, and loess groups (see figure 5 and table 2). This gives a preliminary indication that the final results will not show a great dependence on the actual variations in model velocities, but will be more sensitive to the thickness of the unconsolidated soils. This implies that future similar work should emphasize obtaining good soil thickness models. 

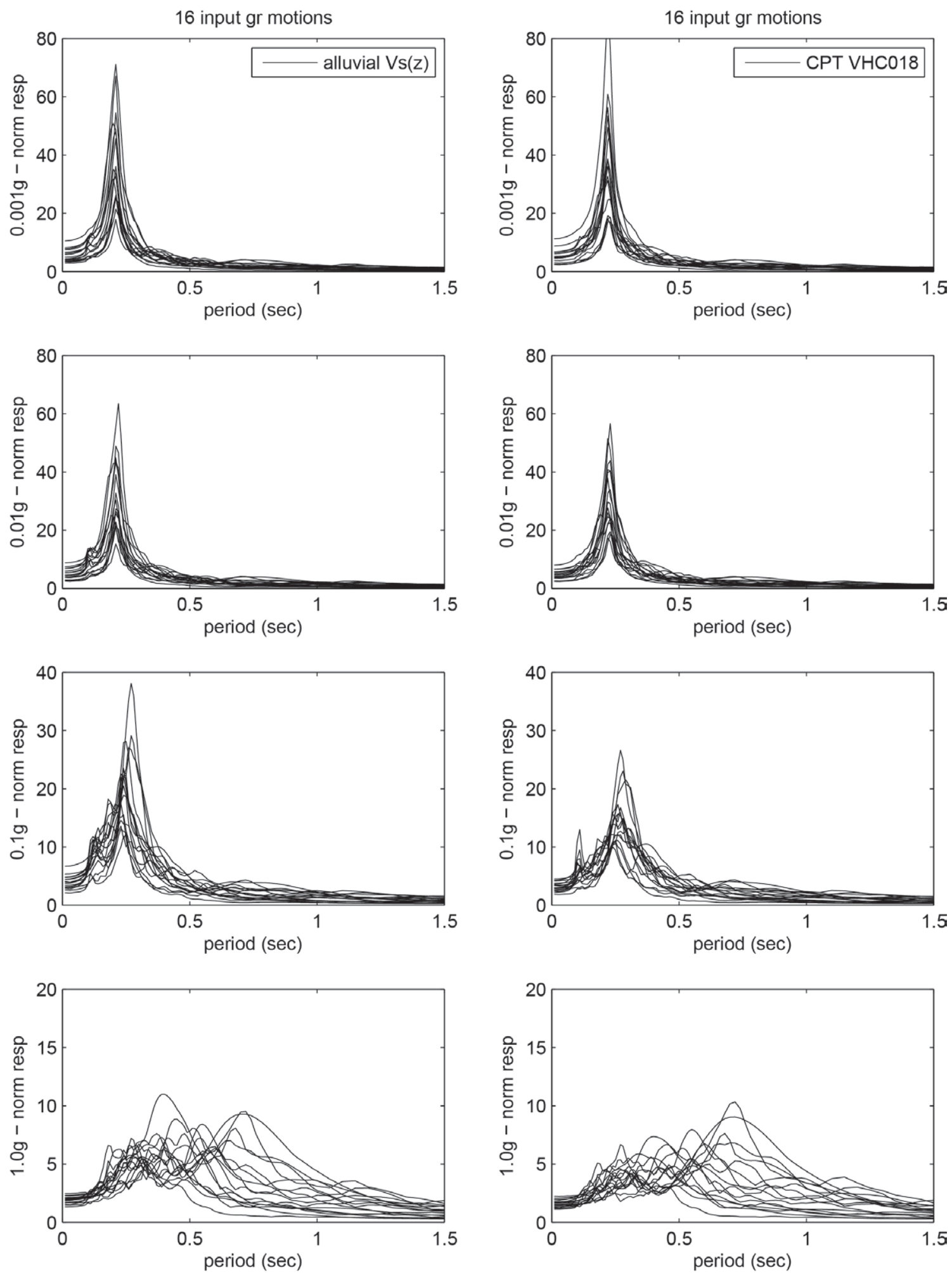

Figure 10. Normalized spectral response for the 16 ground motions listed in table 3 for (left column) the depth-dependent alluvial group profile and (right column) CPT profile VHC018. From top to bottom in order, the input ground motions have been scaled to PGA values of 0.001 times the acceleration of gravity $(\mathrm{g}), 0.01 \mathrm{~g}, 0.1 \mathrm{~g}$, and $1.0 \mathrm{~g}$ respectively. 


\section{Site Amplification Calculation}

One approach for estimating probabilistic seismic hazard that incorporates near surface soil information is to assume that the acceleration levels in the probabilistic seismic hazard map can be multiplied by an amplification factor that has been estimated or calculated for each individual site. While the PSHA acceleration levels consider uncertainties in source and attenuation, this method does not take into account the uncertainty in the knowledge of the amplification factor or the uncertainty in the profile properties from which the amplification was derived. Thus, this type of calculation is not completely probabilistic. The methodology developed for a completely probabilistic calculation incorporating site effects (Cramer, 2003) has been successfully applied to the Memphis area (Cramer and others, 2004). In that study, site amplification factors were calculated that indicate how bedrock ground motions are amplified or deamplified depending on the soil conditions, and depending as well on the uncertainty in that amplification. The site amplification factors have some uncertainty because they are calculated based on soil properties and thickness that also have some uncertainty.

For the amplification calculation, the rasterized bedrock depth was sampled at 0.01degree intervals, and the appropriate uncertainty was assigned to the depth based on the fit of the bedrock depth surface to the original depth point data. For each of these points, the predominant geologic unit was selected for that cell in order to select the appropriate shearwave velocity reference profile, and the profile was truncated at the bedrock depth for that point. One hundred realizations of the soil profile were generated that have the distribution of shear-wave velocities and soil-layer thicknesses that are found in the measured profiles.

As no in-situ measurements were available, generic values for the dynamic soil properties (shear-modulus reduction curves and damping curves) were assumed to be those represented by the Electric Power Research Institute (EPRI)(1993) for sands, depending on the depth range, and by Vucetic and Dobry (1991) for clays. The set of realizations also introduces variations from these average modulus reduction curves and damping curves with natural lognormal standard deviation of 0.35 (EPRI, 1993).

Random variation was introduced into the scaled input bedrock ground motions by selecting from a set of 16 ground motions for each realization (table 3). The 100 random realizations of soil profiles were used as input to the site response calculation to create a distribution of possible site-amplification factors at each site for varying levels of input ground motion at the bedrock interface.

For each frequency of interest, the site response was computed using input ground motions scaled from $0.01 \mathrm{~g}$ to $1.0 \mathrm{~g}$ in response spectral amplitude for that particular frequency of interest (PGA, 0.2-s SA, 1.0-s SA) to obtain the output amplification. Each frequency's site amplification distribution was calculated separately with input seismograms scaled to a given response spectral level at that frequency. (There was no approximation made to scale a PGA value using a standard response spectral shape, which would require further corrections that are not needed if the response is scaled directly at the frequency of interest.)

The scaling at specific frequencies also makes the calculation less sensitive to differences in input spectral shape between earthquakes selected in table 3 and spectra for large earthquakes in the eastern United States. Inclusion of synthetic ground motions calculated for the eastern United States in table 3 also help account for these differences in the distribution of amplification factors. 
The median and lognormal standard deviation of the amplification factors were tabulated at each input ground motion level. Maps of the amplification factor are presented in figure 11 for selected input ground motion levels $(0.05 \mathrm{~g}, 0.2 \mathrm{~g}$ and $0.5 \mathrm{~g})$. There is a clear correlation with bedrock depth in the resulting maps.

The amplification for PGA strongly correlates with the surficial geology described by the terrace and lacustrine groups, where the amplification is a factor of nearly 3 . The smallest amplification is seen in the southeastern quadrangle where bedrock is found at or near the surface. The nonlinear response for large input ground motions is seen in the decrease in mean PGA amplification over the entire area to a factor less than 1.5 for large ground motions.

The amplification at 0.2-s period is greatest around the edges of the uplands where soil depths lead to resonant frequencies of 0.2 to $0.3 \mathrm{~s}$. Amplification factors reach 4.3 in these areas for small input ground motions. Average amplification decreases from 2.9 to 1.5 with increasing input ground motion level, and deamplification occurs at some sites near the center of the study area for $0.5 \mathrm{~g}$ input motions.

For 1.0-s period, strong amplification occurs within the steep sided ancient bedrock valley beneath the Ohio River flood plain. There is a large change in amplification factor in the bedrock valley, from 3.5 to 2.1 as input ground motion levels increase. The overall patterns seen in the amplification are what would be expected given the bedrock depth model. Amplification and deamplification will have a large effect on the probabilistic seismic hazard.

\section{Possible Need for a 3D Response Calculation}

The bedrock model that has been developed has a relatively steep sided bedrock valley underlying the Ohio River and associated flood plain. Because the resulting amplification maps show a strong dependence on the soil thickness at the edges of this bedrock valley, future work should address the extent to which the 3D geometry affects soil response. Calculating the 1D response using laterally varying 1D soil profiles using Shake91 has been applied for this type of study in other areas, such as Charleston, South Carolina (Silva and others, 2003; Chapman and others, 2006); St. Louis, Missouri (Williams and others, 2007); Memphis, Tennessee (Cramer and others, 2004; Cramer, 2006); and in the St. Lawrence River valley near Ottawa, Canada (Benjumea and others, 2008; Motazedian and Hunter, 2008), however, it may not fully capture the 3D response near the bedrock valley edges in the Evansville area. Now that a $3 \mathrm{D}$ velocity depth model has been developed, this region is a strong candidate for further study using a 3D site response calculation method to investigate possible basin effects, however that is beyond the scope of the present study. The effects of liquefaction, complex nonrandom variations in Vs within a region that we treat with random variations from a single reference profile, and more complex variations in bedrock velocity could also affect the true response at a site. Further work should also be focused on the collection and analysis of additional seismic data in order to validate the amplifications calculated with the model, especially at locations where infrastructure and population are most likely to be affected. While possible earthquake sources for these measurements are rare, methods that use horizontal to vertical ratio of noise recordings, for example, are one way that the lateral variation of response could be tested, at least for lower input ground motion levels. 


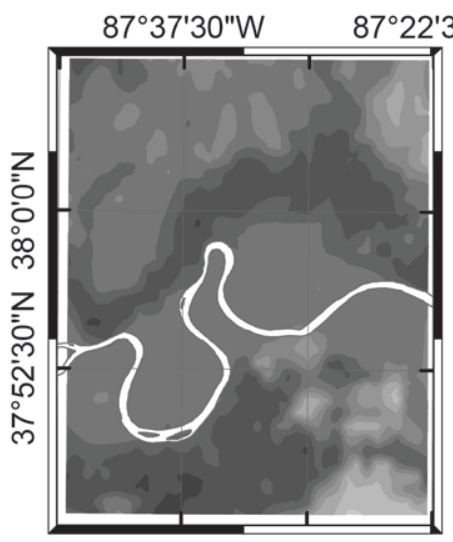

PGA $0.05 \mathrm{~g}$ input

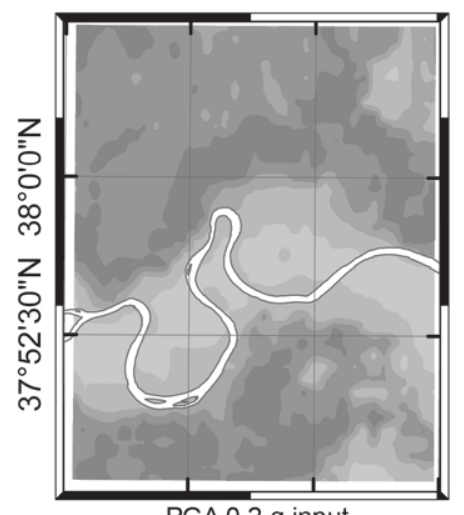

PGA $0.2 \mathrm{~g}$ input

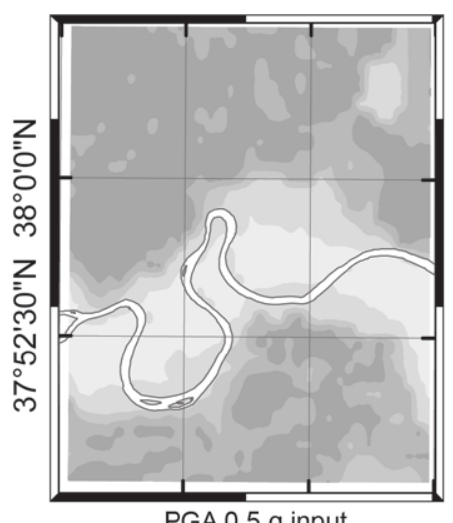

PGA $0.5 \mathrm{~g}$ input

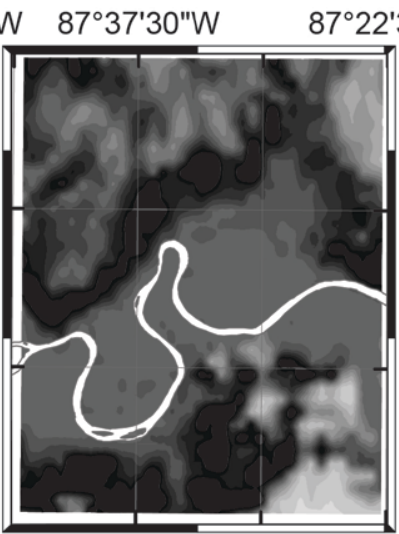

0.2 -s period $0.05 \mathrm{~g}$ input

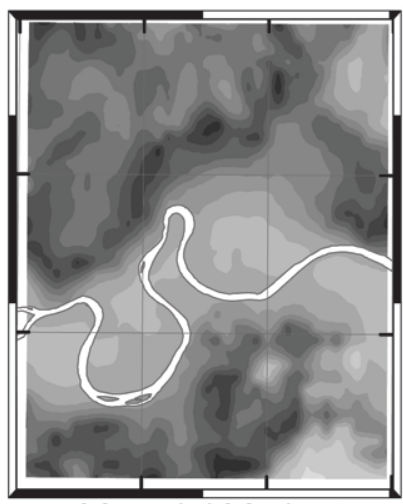

0.2 -s period $0.2 \mathrm{~g}$ input

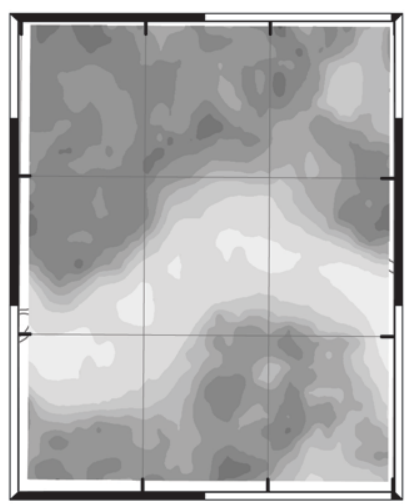

0.2 -s period $0.5 \mathrm{~g}$ input

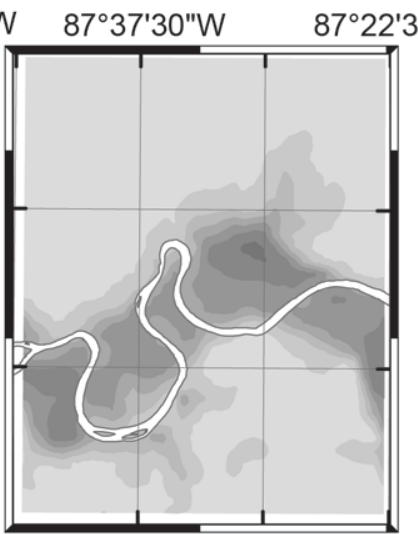

1.0 -s period $0.05 \mathrm{~g}$ input

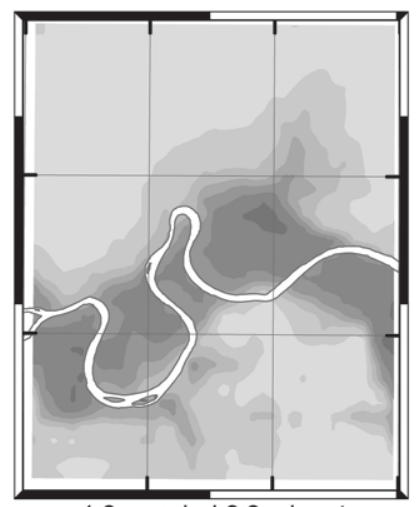

Amplification

1.0-s period $0.2 \mathrm{~g}$ input

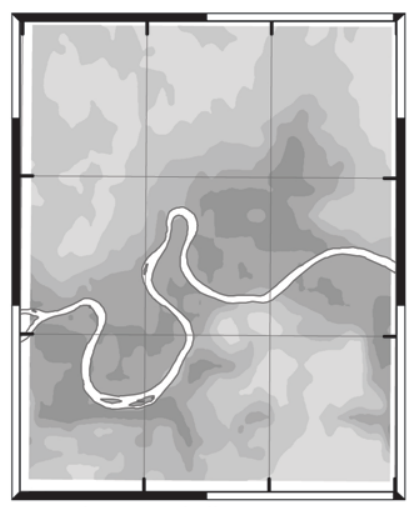

1.0 -s period $0.5 \mathrm{~g}$ input

0.5-0.75

$0.75-1$

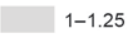

1.25-1.5

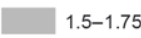

$1.75-2$

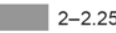

2.25-2.5

$2.5-2.75$

2.75-3

3-3.25

$3.25-3.5$

$3.5-3.75$

$3.75-4$

$4-4.25$

$4.25-4.5$

Figure 11. Results of the calculation of site amplification relative to input bedrock ground motion. Left column is PGA amplification, middle column is amplification at 0.2-s spectral acceleration, right column is amplification at 1.0-s spectral acceleration.

\section{Probabilistic Seismic Hazard Calculation and Results}

The amplification factors computed in the previous section are incorporated into the calculation of the probabilistic seismic hazard. Within the probabilistic seismic hazard calculation for a given site, the attenuation curves are modified from the $\mathrm{B} / \mathrm{C}$ site assumptions included in attenuation relations used in the national hazard maps to rock conditions, then modified based on the amplification factor distribution at the site to 
provide new attenuation curve values with the additional uncertainties incorporated. These modified attenuation curves are used in the probability calculations of ground shaking for the complete range of possible source regions to create the hazard curve at a given site in the grid.

The probabilistic seismic hazard maps have been computed for peak ground acceleration (PGA) and spectral acceleration at 0.2 -s and 1.0 -s periods with 2 percent probability of exceedance (PE) in 50 years (figure 12). The highest PGA values of 0.5 to $0.6 \mathrm{~g}$ are found in the upland areas on the north and south side of the Ohio River. The 0.2-s spectral acceleration reaches $1.4 \mathrm{~g}$ in localized parts of the upland regions. At 1.0 -s period, the higher accelerations of 0.3 to $0.5 \mathrm{~g}$ are strictly limited to the ancient Ohio bedrock valley beneath the flood plain, and elevated levels are found in the major ancient bedrock tributaries leading into the Ohio valley. 
Background 2008 USGS 2 percent probability of exceedence in 50 years with B/C site conditions

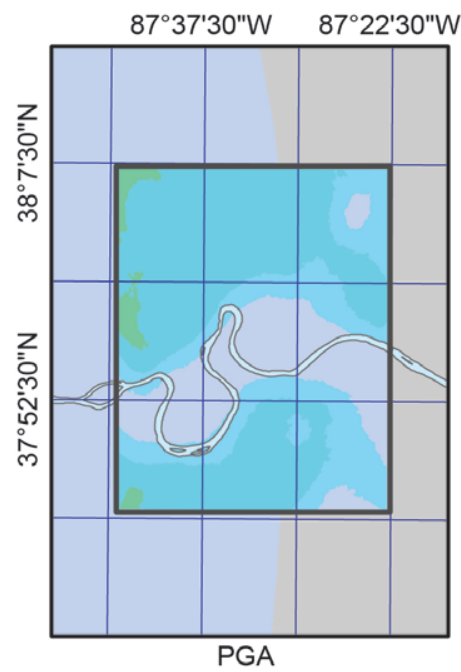

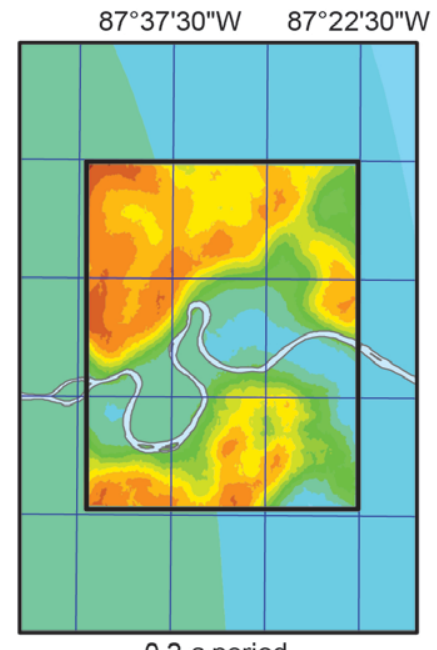

0.2 -s period

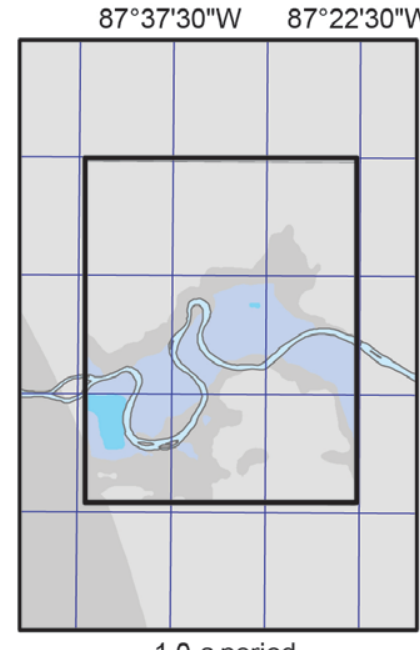

1.0-s period

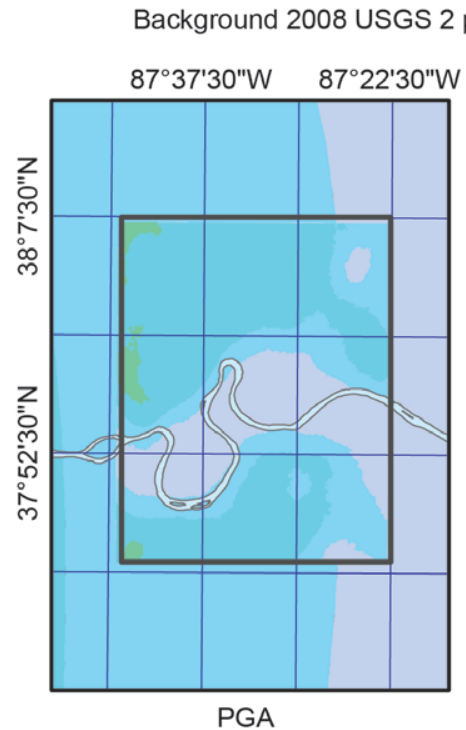

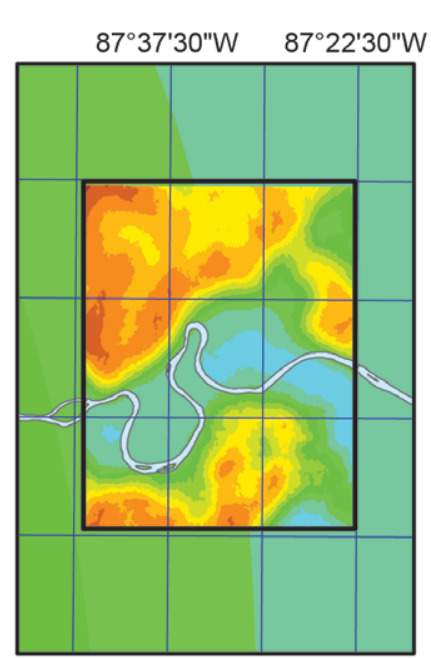

0.2 -s period

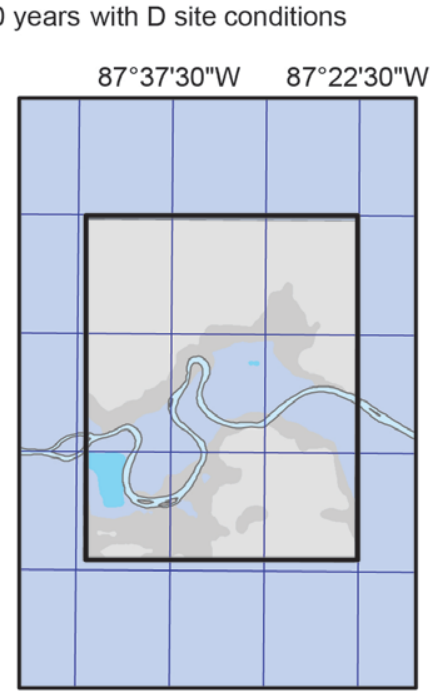

1.0-s period
Acc $(\mathrm{g})$

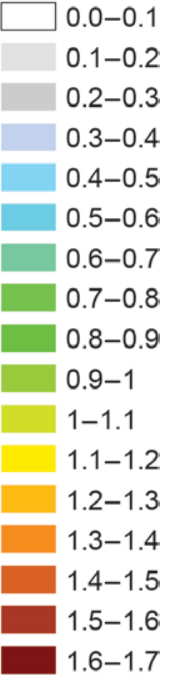

Figure 12. (top) Comparison of probabilistic seismic hazard analysis including site effects (inset) with the USGS 2008 national maps for NEHRP site class B/C shown in the surrounding background, (bottom) Comparison of probabilistic seismic hazard analysis including site effects (inset) with the USGS 2008 national maps for NEHRP site class D shown in the surrounding background.

In general, by considering the effect of local site conditions on ground motions, the estimates of probabilistic ground motion having 2 percent probability of being exceeded in 50 years have increased, compared with the values of the USGS 2008 national seismic hazard maps, which assume NEHRP class B/C site conditions with an average shear-wave velocity of $760 \mathrm{~m} / \mathrm{s}$ in the top $30 \mathrm{~m}$. The PGA ranges from 0.3 to $0.6 \mathrm{~g}$, compared to the values 0.2 to $0.4 \mathrm{~g}$ provided in the national maps. PSHA 0.2-s spectral accelerations range from 0.6 to $1.5 \mathrm{~g}$, for the uplands areas and lacustrine deposits with thin to moderately thick soils, compare to 0.5 to $0.7 \mathrm{~g}$ in the national maps. PSHA 1.0-s spectral accelerations range from around 0.1 to $0.2 \mathrm{~g}$, which are comparable to the national map values, with the 
exception of the area overlying the ancient bedrock valley, where the values are $0.4 \mathrm{~g}$, with areas as high as $0.5 \mathrm{~g}$ concentrated within the far western limits of the ancient bedrock valley.

Since the soil types of the Evansville area have characteristics typical of NEHRP class D site conditions (180-360 m/s) at the surface, it is relevant to compare the PSHA results that include site amplification to the national map values with a site $\mathrm{D}$ amplification factor applied (BSSC, 2004) (figure 12, lower row). The PSHA maps for PGA with completely probabilistic treatment of site effects can then be seen to have values even greater than those provided in the national maps with NEHRP class D conditions, with some deamplification within the thick soils of the ancient bedrock valley. The PSHA $0.2-\mathrm{s}$ spectral accelerations are also much greater than the 0.6 to $0.8 \mathrm{~g}$ values for the USGS 2008 national maps with site $\mathrm{D}$ conditions. The deamplification within the thick soils of the ancient bedrock valley leads to values lower than the D site class predictions in those regions. The high resolution PSHA 1.0-s spectral accelerations including site effects are seen to be comparable to the national map values with $\mathrm{D}$ site conditions within the limits of the ancient bedrock valley, but significantly less than the national map values outside those limits.

Several factors could contribute to the difference between the completely probabilistic estimates and those predicted using the NEHRP site classes. First, the NEHRP amplification factors are derived from data outside the CEUS. Second, while materials at the surface appear to have class D type seismic velocities, the thickness varies, and in particular thinner soils (less than $25 \mathrm{~m}$ ) surrounding the Ohio River valley will not have resonances near 1.0-s. Third, deamplification for large input ground motions can limit the maximum accelerations. This deamplification in the calculation results from shear-wave modulus reduction and damping curves iteratively applied in the site response calculation. The modulus reduction curves are based on general soil properties, so more work should be aimed at improving our knowledge of these properties with in-situ measurements.

\section{Conclusions}

Detailed geologic mapping and comprehensive S-CPT sampling of soil profiles in the Evansville region now make it possible to estimate site amplification and its uncertainty with a high level of detail. The unique depositional history of the soils in the region creates several distinct soil profile types that are distinguishable based on their seismic velocity and their major constituent soil type. The response for each type of soil has been characterized statistically in this study. The amplification patterns that emerge at all frequencies are strongly controlled by the local geology and the soil thickness. The distributions of the amplification factors (median and log standard deviation) have been characterized at each 0.01 degree grid point within the region, by calculating site response with 100 realizations of the soil profile properties. The distributions of amplification factors are then used in a completely probabilistic methodology for including site effects in the probabilistic hazard calculation. The resulting PSHA maps of acceleration with 2 percent probability of exceedance in 50 years show patterns with strong local variations, and which exceed locally the national seismic hazard map values with $\mathrm{B} / \mathrm{C}$ site conditions. When compared to the national maps with a site D class amplification factor applied, the values for PGA and 0.2-s SA are larger. There are large local differences between the national maps with a site D class amplification factor and the high-resolution PSHA maps for PGA 
and 0.2-s SA, which illustrate the importance of the high-resolution seismic hazard analysis in this type of environment.

\section{Acknowledgments}

This work was supported by USGS NEHRP Awards 05HQGR0033 and 07HQGR0058. The surficial geologic mapping was carried out as part of the Evansville Area Earthquake Hazards Mapping Project. We would like to acknowledge the contribution to the mapping from Ronald C. Counts, Steven L. Martin, Michael L. Murphy, Mark F. Thompson, and William "Drew" Andrews of the Kentucky Geological Survey, and Dave Moore and Scott Lundstrom of the USGS. We would like to thank Tom Holzer, Thomas Noce and the USGS for collecting and making available the new high quality SCPT observations in the area. We thank Josh Messmer for assistance with figure preparation for this article. Access to point data and other databases was greatly facilitated by John Hill and others at the IGS, who maintain and provide GIS databases. We acknowledge the efforts of Joan Gomberg, and Eugene "Buddy" Schweig, of the USGS, Jim Cobb, John Kiefer and Dave Williams of the KGS, John Steinmetz of the IGS and Christine Martin of the Southwest Indiana Disaster Resistant Community Corporation for providing continuing interest in the results of the group effort to create the seismic hazard maps. We thank Stephen Harmsen, Charles Mueller, and David Perkins for insightful reviews that helped improve the manuscript.

\section{References}

Bakun, W.H., and Hopper, M.G., 2004, Magnitudes and locations of the 1811-1212 New Madrid, Missouri, and the 1886 Charleston, South Carolina, earthquakes: Bulletin of the Seismological Society of America, v. 94, no. 1, p. 64-75.

Bauer, R.A., and CUSEC State Geologists, 2005, Central U.S. shear wave velocity database with accompanying geological/geotechnical information of nonlithified geologic materials: Central United States Earthquake Consortium United States Geological Survey External Research Program Final Report 04HQGR0074, 29 p.

Benjumea, B., Hunter, J.A., Pullan, S.E., Brooks, G.R., Pyne, M., and Aylsworth, J.M., 2008, Vs(30) and fundamental site period estimates in soft sediments of the Ottawa Valley from near-surface geophysical measurements: Journal of Environmental and Engineering Geophysics, v. 13, no. 4, p. 313-323.

Beresnev, I.A., and Atkinson, G., 2002, Source parameters of earthquakes in eastern and western North America based on finite-fault modeling: Bulletin of the Seismological Society of America, v. 92, no. 2, p. 660-682.

Bleuer, N.K., 2000, iLITH database of the Indiana Geological Survey: Indiana Geological Survey Open File Study 00-8 on CD-ROM.

Building Seismic Safety Council, 2004, National Earthquake Hazards Reduction Program recommended provisions for seismic regulations for new buildings and other structures (FEMA 450), Part 1: Provisions: Building Seismic Safety Council, 356 p.

Chapman, M.C., Martin, J.R., Olgun, C.G., and Beale, J.N., 2006, Site-response models for Charleston, South Carolina, and vicinity developed from shallow geotechnical investigations: Bulletin of the Seismological Society of America, v. 96, no. 2, p. 467-489. 
Cornell, C.A., 1968, Engineering seismic risk analysis: Bulletin of the Seismological Society of America, v. 58, no. 5, p. 1583-1606.

Cramer, C., Gomberg, J.S., Schweig, E.S., Waldron, B.A., and Tucker, K., 2004, The Memphis, Shelby County, Tennessee, seismic hazard maps U.S. Geological Survey Open-File Report 2004-1294, 46 p.

Cramer, C.H., 2003, Site specific seismic hazard analysis that is completely probabilistic: Bulletin of the Seismological Society of America, v. 93, no. 4, p. 1841-1846.

Cramer, C.H., 2006, Quantifying the uncertainty in site amplification modeling and its effects on site-specific seismic hazard estimation in the upper Mississippi embayment and adjacent areas: Bulletin of the Seismological Society of America, v. 96, no. 6, p. 2008-2020.

Eggert, D.L., Samuelson, A.C., Bray, J.D., Chang, C.W., Eckhoff, W.R., Kayabali, K., McClees, E.J., West, T.R., Woodfield, M.C., and Zheng, B., 1994, Final report to the city of Evansville: Shear-wave and earthquake hazard mapping of Evansville, Indiana: Indiana Geological Survey Open File Studies, OFS94-19, 17 p.

Eggert, D.L., Woodfield, M.C., Bleuer, N.K., and Hartke, E.J., 1996, Geologic terrain map of the Indiana portion of the Newburgh quadrangle, Indiana-Kentucky: Indiana Geological Survey Open File Studies, OFS96-09.

Eggert, D.L., Woodfield, M.C., Bleuer, N.K., and Hartke, E.J., 1997a, Geologic terrain map of the Daylight quadrangle: Indiana Geological Survey Open File Studies, OFS9717,2 pl.

Eggert, D.L., Woodfield, M.C., Bleuer, N.K., and Hartke, E.J., 1997b, Geologic terrain map of the Evansville region, Indiana: Indiana Geological Survey Open File Studies, OFS97-16.

Electric Power Research Institute, 1993, Guidelines for determining design basis ground motions, vol.1-5, TR-102293: Electric Power Research Institute TR-102293.

Frankel, A., Mueller, C., Barnhard, T., Perkins, D., Leyendecker, E.V., Dickman, N., Hanson, S., and Hopper, M., 1996, National seismic hazard maps: Documentation June 1996 U.S. Geological Survey Open-File Report 96-532, 110 p.

Frankel, A., Petersen, M., Mueller, C., Haller, K., Wheeler, R., Leyendecker, E.V., Wesson, R., Harmsen, S., Cramer, C., Perkins, D., and Rukstales, K., 2002, Documentation for the 2002 update of the national seismic hazard maps: U.S. Geological Survey Open-File Report 02-420, 33 p.

Gray, H.H., 1983, Map of Indiana showing thickness of unconsolidated deposits: Indiana Geological Survey, Miscellaneous Map 37, scale 1:500,000.

Gray, H.H., 1989, Quaternary geologic map of Indiana; Indiana Geological Survey Miscellaneous Map 49, scale 1:500,000.

Green, R.A., Obermeier, S.F., and Olson, S.M., 2005, Engineering geologic and geotechnical analysis of paleoseismic shaking using liquefaction effects: Field examples: Engineering Geology, v. 76, p. 263-293.

Holzer, T.L., 2003, Earthquake Hazards: USGS CPT Data-Evansville Indiana area: United States Geological Survey Earthquake Hazards Program, accessed January 14, 2004, at http://earthquake.usgs.gov/regional/nca/cpt/data.

Hough, S.E., Armbruster, J.G., Seeber, L., and Hough, J.F., 2000, On the modified Mercalli intensities and magnitudes of the 1811-1812 New Madrid earthquakes: Journal of Geophysical Research-Solid Earth, v. 105, no. B10, p. 23839-23864. 
Idriss, I.M., and Sun, J.I., 1992, User's manual for SHAKE91: Center for geotechnical modeling; University of California, Department of Civil and Environmental Engineering, $47 \mathrm{p}$.

Johnston, A.C., 1996, Seismic moment assessment of earthquakes in stable continental regions: II. New Madrid 1811-1812, Charleston 1886 and Lisbon 1755: Geophysical Journal International, v. 126, no. 2, p. 314-344.

Kramer, S.L., 1996, Geotechnical earthquake engineering: New Jersey, Prentice Hall, 653 p.

McGuire, R.K., 2004, Seismic hazard and risk analysis: Earthquake Engineering Research Institute MNO-10, $221 \mathrm{p}$.

Moore, D.W., Lundstrom, S.C., Counts, R.C., Martin, S.L., Andrews, W.M., Jr., Newell, W.L., Murphy, M.L., Thompson, M.F., Taylor, E.M., Kvale, E.P., and Brandt, T.R., 2009, Surficial geologic map of the Evansville, Indiana and Henderson, Kentucky area: U.S. Geological Survey Scientific Investigations Map SIM-3069, 1:50,000 scale.

Motazedian, D., and Hunter, J., 2008, Development of an NEHRP map for the Orleans suburb of Ottawa, Ontario: Canadian Geotechnical Journal, v. 45, no. 8, p. 1180-1188.

Munson, P.J., Munson, C.A., and Pond, E.C., 1995, Paleoliquefaction evidence for a strong Holocene earthquake in south-central Indiana: Geology, v. 23, no. 4, p. 325-328.

Nuttli, O.W., 1973, The Mississippi Valley earthquakes of 1811 and 1812: Intensities, ground motion and magnitudes: Bulletin of the Seismological Society of America, v. 63, no. 1, p. 227-248.

Olson, S.M., Green, R.A., and Obermeier, S.F., 2005, Revised magnitude-bound relation for the Wabash Valley seismic zone of the central United States: Seismological Research Letters, v. 76, no. 6, p. 756-771.

Pacific Earthquake Engineering Research Center, 2009, PEER strong motion database: Berkeley, California, v. 2009, no. January 1.

Petersen, M.D., Frankel, A.D., Harmsen, S.C., Mueller, C.S., Haller, K.M., Wheeler, R.L., Wesson, R.L., Zeng, Y.H., Boyd, O.S., Perkins, D.M., Luco, N., Field, E., Wills, C.J., and Rukstales, K.S., 2008, Documentation for the 2008 update of the national seismic hazard maps: U.S. Geological Survey Open-File Report 2008-1128, 60 p.

Reiter, L., 1990, Earthquake hazard analysis: Issues and insights: New York, N.Y., Columbia University Press, 233 p.

Richter, C.F., 1958, Elementary seismology: W.H. Freeman \& Co, 768 p.

Rudman, A.J., Biggs, M.E., Blakely, R.F., and Whaley, J.F., 1973, Statistical studies of Indiana bedrock velocities: Mapping applications: Indiana Academy of Science, v. 83, no. 1973 , p. 284-290.

Silva, W., Wong, I., Siegel, T., Gregor, N., Darragh, R., and Lee, R., 2003, Ground motion and liquefaction simulation of the 1886 Charleston, South Carolina, earthquake: Bulletin of the Seismological Society of America, v. 93, no. 6, p. 2717-2736.

Street, R., 1984, The historical seismicity of the central United States: 1811-1928 United States Geological Survey Appendix A of Final Report for Contract 14-08-0001-21251, $316 \mathrm{p}$.

U.S. Geological Survey, 2004, 1-arc-second national elevation dataset, U.S. Geological Survey, accessed July 2009 at ftp://edcftp.cr.usgs.gov/pub/data/ned.

Vucetic, M., and Dobry, R., 1991, Effect of soil plasticity on cyclic response: Journal of Geotechnical Engineering, v. 117, p. 89-107. 
Weichert, D.H., 1980, Estimation of the earthquake recurrence parameters for unequal observation periods for different magnitudes: Bulletin of the Seismological Society of America, v. 70, no. 4, p. 1337-1346.

Whaley, J.F., Blakely, R.F., Like, K.K., and James, C.L., 2002, Seismic refraction data for Indiana (Point Shapefile): Bloomington, Indiana, Indiana Geological Survey, accessed October 7, 2002, at http://inmap.indiana.edu/dload_page/geology.html.

Wheeler, R.L., and Cramer, C.H., 2002, Updated seismic hazard in the southern Illinois Basin: geological and geophysical foundations for use in the 2002 USGS national seismic hazard maps: Seismological Research Letters, v. 73, no. 5, p. 776-791.

Williams, R.A., Odum, J.K., Stephenson, W.J., and Herrmann, R.B., 2007, Shallow P- and S-wave velocities and site resonances in the St. Louis region, Missouri-Illinois:

Earthquake Spectra, v. 23, no. 3, p. 711-726.

Publishing support provided by:

Denver Publishing Service Center

For more information concerning this publication, contact:

Center Director, USGS Geologic Hazards Science Center

Box 25046, Mail Stop 966

Denver, CO 80225

(303) 273-8579

Or visit Geologic Hazards Science Center Web site at: http://geohazards.cr.usgs.gov/ 